Original research article

Food Quality and Functionality Section

\title{
In Vitro Characterization of Fluted Pumpkin Leaf Protein Hydrolysates and Ultrafiltration of Peptide Fractions: Antioxidant and Enzyme-Inhibitory Properties
}

\author{
Akinsola Albert Famuwagun ${ }^{1,2 *} \odot$, Adeola Monisola Alashi ${ }^{1}$, Saka Olasunkanmi Gbadamosi ${ }^{2}$, \\ Kehinde Adekunbi Taiwo ${ }^{2}{ }^{\oplus}$, Durodoluwa Joseph Oyedele ${ }^{3}$, Odunayo Clement Adebooye ${ }^{4}$, Rotimi Emmanuel Aluko ${ }^{1}\left({ }^{\circledR}\right.$ \\ ${ }^{I}$ Department of Food and Human Nutritional Sciences, University of Manitoba, R3T 2N2 Winnipeg, Canada \\ ${ }^{2}$ Department of Food Science \& Technology, Obafemi Awolowo University, 220002 Ile-Ife, Nigeria \\ ${ }^{3}$ Department of Soil and Land Resources Management, Faculty of Agriculture, \\ Obafemi Awolowo University, 220002 Ile-Ife, Nigeria \\ ${ }^{4}$ Department of Agronomy, Faculty of Agriculture, Obafemi Awolowo University, 220002 Ile-Ife, Nigeria
}

Key words: fluted pumpkin leaf, protein hydrolysates, membrane ultrafiltration, antioxidant activity, antidiabetic activity, antihypertensive activity

Hydrolysates were produced using Alcalase ( $\mathrm{AH})$, chymotrypsin $(\mathrm{CH})$, pepsin $(\mathrm{PH})$, and trypsin $(\mathrm{TH})$, and also fluted pumpkin leaf protein isolate (FLI) as a substrate. AH had the lowest degree of hydrolysis (16.37\%) but exhibited overall superior antioxidant and enzyme inhibitory properties. Therefore, it was fractionated by membrane ultrafiltration to give $<1,1-3,3-5,5-10$, and $>10 \mathrm{kDa}$ peptide fractions. Gel permeation chromatography showed that the molecular weight of the FLI was $19.77 \mathrm{kDa}$ and that of the hydrolysates was below $7.5 \mathrm{kDa}$. The hydrolysate peptides had a high content of hydrophobic amino acids but low levels of sulfur-containing amino acids, when compared to protein of FLI. Peptide sequence analysis showed that the hydrolysates consisted of dipeptides, tripeptides, and tetrapeptides with molecular weights below 500 Da. The hydrolysates were also stronger inhibitors of linoleic acid oxidation, $\alpha$-amylase, $\alpha$-glucosidase, and angiotensin converting enzyme (ACE) than FLI. Among the fractions, the $<1$ and $1-3 \mathrm{kDa}$ were the most effective free radical scavengers and metal chelators in addition to their strong inhibitory activities against $\alpha$-amylase, $\alpha$-glucosidase, and ACE. We conclude that the $\mathrm{AH}$ and low molecular weight peptide fraction $(<3 \mathrm{kDa})$ could find applications in formulating foods with various bioactive properties.

\section{INTRODUCTION}

Proteins are integral food compounds that provide nutritional, technological, and functional properties. In addition to these properties, proteins can give rise to bioactive peptides or hydrolysates, which show certain specific properties such as antioxidant, antihypertensive, and antidiabetic activities [Chalamaiah et al., 2017]. The various properties of these hydrolysates and peptides make them applicable as potential agents in the treatment, prevention, and amelioration of various diseases as well as in the shelf life extension of food products [Ortiz-Martinez et al., 2014]. Bioactive peptides from foods are obtained after enzymatic hydrolysis, because the active sequences lie within the primary structure of the proteins [Aluko, 2015; Ramada et al., 2017]. Based on this fact, the study of protein hydrolysates has become a new area in biochemical and nutritional research. Enzymatic hydrolysis has been an effective way of releasing these peptides from the precursor proteins because it preserves the functionalities of the peptides. The properties of enzy-

\footnotetext{
* Corresponding Author: Tel.: +2347038688258;

E mail: akinsolaalbert@gmail.com (Dr. A. Famuwagun)
}

matic hydrolysates depend on the primary structure of parent protein(s), degree of hydrolysis (DH), nature of protease(s) used, and the type of peptides released during the hydrolysis such as their molecular weight and amino acid composition and sequence [Mirzaei et al., 2016]. Variations in the specificities of enzymes used during protein hydrolysis are important to the hydrolysates because the same protein chain can produce different peptides when cleaved by different proteases [Tavano, 2013]. After hydrolysis, peptides that were inactive in the intact proteins are released and can be further fractionated into peptides of varying molecular weights using an ultrafiltration membrane; the fractions may then be evaluated for bioactive functions.

The human body is constantly subjected to various activities, leading to oxidative stress, which sometimes leads to overpowering of the intrinsic antioxidant defense mechanism of the body. Overwhelming of the in-built defense system may occur as a result of many factors which may lead to reactive oxygen species accumulating as reactive radicals that cause severe damages to the body [Wei et al., 2001; Yoshikawa \& Naito, 2002]. To expand the treatment options, antioxidant peptides that target the reduction of oxidative stress would be of interest [McCarthy et al., 2013]. Consumption of natural dietary supplements, such as peptides, 
with varieties of antioxidant compounds may help to augment the body defense mechanism against the free radicals. Antioxidant peptides exert their activity through multiple pathways such as scavenging free radicals, chelating transition metals, and reducing ferric irons [Ramada et al., 2017]. These peptides inhibit oxidative processes that lead to the formation of harmful radicals, which cause various diseases such as cardiovascular impairment (including hypertension and atherosclerosis), cancer, and diabetes [Yoshikawa \& Naito, 2002]. Several peptides and hydrolysates with antioxidant properties have been produced from plant materials such as hemp seed [Girgih et al., 2011], canola seed [Alashi et al., 2014], kariya [Gbadamosi \& Famuwagun, 2016], and alfalfa leaf [Xie et al., 2016].

Hypertension is a risk factor of cardiovascular disease, stroke, and end stage renal disease [Kim \& Byun, 2012]. The angiotensin-I converting enzyme (ACE) in the renin-angiotensin system regulates blood pressure in the human body and catalyzes the cleavage of the $\mathrm{C}$-terminal dipeptide from inactive angiotensin I to produce the active angiotensin II, in addition to inactivating bradykinin, a potent vasodilator [Cao et al., 2010]. Therefore, ACE inhibition is important to controlling the blood pressure. ACE-inhibitory peptides have been produced from various plant proteins such as cotton seed [Filho et al., 2020], soy protein [Wang et al., 2019], canola [Alashi et al., 2014], oat [Bleakley et al., 2017], peanut [Gong et al., 2017], and rice [Pinciroli et al., 2019].

Diabetes mellitus is an endocrine system disease that causes disruption in the normal metabolic process arising from multiple organ damage syndromes [Arise et al., 2016]. Inhibition of enzymes, such as $\alpha$-amylase and $\alpha$-glucosidase, will slow down the digestion and absorption of glucose in the intestine and is therefore, one of the key approaches in controlling diabetes. Enzymatic hydrolysis of plant protein has been used to release many potential antidiabetic peptides such as pea seed [Awosika \& Aluko, 2019], watermelon seed [Arise et al., 2016], and soy protein [Wang et al., 2019]. Therefore, peptides with multifunctional activities have been suggested to tackle the damaging effects of excessive levels of $\alpha$-amylase, $\alpha$-glucosidase, ACE, and toxic free radicals in the body [Gong et al., 2017].

Proteins obtained from leaves represent a good source of nutrition for human [Aletor et al., 2002]. Fluted pumpkin leaf (Telfairia occidentalis) is one of the most widely consumed leafy vegetables in Nigeria [Odiaka, 2001]. The leaf is available all year round in Nigeria depending on water availability and is used to prepare various dishes. The dried leaf powder has about $30.05-32.82 \%$ protein content [Nnamezie et al., 2019; Udousoro \& Ekanem, 2013], which is comparable with some seed proteins. This high level of protein in fluted pumpkin dried leaf could enhance its use in the production of high-quality protein products.

Protein has been isolated from fluted pumpkin dried leaf and characterized [Famuwagun et al., 2020]. However, there is no published work on fluted pumpkin leaf protein hydrolysates, especially on their antioxidant and enzyme inhibitory activities. This study determined the antioxidant and enzyme inhibitory activities of fluted pumpkin leaf protein hydrolysates produced using four different food grade proteases. The most active protein hydrolysate was then fractionated using the ultrafiltration membrane method. The fractions were tested for antioxidant, antidiabetic ( $\alpha$-amylase and $\alpha$-glucosidase inhibition), and antihypertensive (angiotensin-converting enzyme inhibition) activities.

\section{MATERIALS AND METHODS}

\section{Preparation of dried leaf powder}

Fresh leaves of fluted pumpkin leafy vegetables were obtained from accredited Microveg farmer in Osun State, Nigeria. The leaves were sorted, destalked, rinsed, and subsequently oven-dried using a hot air oven (Uniscope SM9053 Laboratory Oven, Singerfried, England) at a drying temperature of $55 \pm 2^{\circ} \mathrm{C}$ for $8 \mathrm{~h}$. The dried leaves were milled to powder with a laboratory blender (VLC sapphire grinder, IS-4930, Edinburgh, England). The milled powder was subjected to acetone extraction at a ratio of 1:10 (leaf powder:acetone, $w / v)$. The purpose of this was to remove any form of interfering compound (such as polyphenol) during protein isolation. The leaf powder/acetone suspension was continuously stirred on a magnetic stirrer for $2 \mathrm{~h}$ and later filtered using muslin cloth. The residue obtained was again extracted with acetone and the resulting residue was air-dried in the fume hood at room temperature for $48 \mathrm{~h}$ to ensure the escape of residual acetone from the residue. This was then packaged as fluted pumpkin leaf powder and stored at $-20^{\circ} \mathrm{C}$.

\section{Preparation of fluted pumpkin leaf isolate and enzymatic hydrolysates}

The fluted pumpkin leaf isolate (FLI) was obtained by a combined method of solubilization, precipitation, and neutralization described by Malomo et al. [2014], which was slightly modified. A suspension of fluted pumpkin leaf powder in deionized water was prepared at a 5\% $(w / v)$ concentration. The suspension was adjusted to $\mathrm{pH} 10.0$ with $2 \mathrm{M} \mathrm{NaOH}$ and then stirred continuously for $1 \mathrm{~h}$ at $37^{\circ} \mathrm{C}$. The residue was separated from the solution by centrifuging at $3500 \times g$ for $30 \mathrm{~min}$ at $4^{\circ} \mathrm{C}$. The supernatant was collected and adjusted to $\mathrm{pH} 4.5$ using $2 \mathrm{M} \mathrm{HCl}$ and stirred for $20 \mathrm{~min}$. The precipitate obtained after centrifugation was washed twice with distilled water to remove salt, re-dispersed in deionized water, and freeze dried to obtain the fluted pumpkin protein isolate. The FLI was hydrolyzed using four different proteases (purchased from Sigma-Aldrich, St. Louis, MO, USA), namely Alcalase ( $>2.4 \mathrm{U} / \mathrm{g}$ ), chymotrypsin ( $>250$ units $/ \mathrm{mg}$ ), pepsin ( $>250$ units $/ \mathrm{mg}$ ), and pancreatin ( $>250$ units $/ \mathrm{mg}$ ) at an enzyme:substrate ratio of 1:100. Different hydrolysis conditions were employed as follows: Alcalase $\left(\mathrm{pH} 8.0,50^{\circ} \mathrm{C}\right)$; trypsin $\left(\mathrm{pH} 8,37^{\circ} \mathrm{C}\right)$; pepsin $\left(\mathrm{pH} 2.0,37^{\circ} \mathrm{C}\right)$, and chymotryp$\sin \left(\mathrm{pH} 8.0,37^{\circ} \mathrm{C}\right)$. The $\mathrm{pH}$ of the hydrolysis process was maintained using either $1 \mathrm{M} \mathrm{NaOH}$ or $1 \mathrm{M} \mathrm{HCl}$ as appropriate, while temperature was kept constant with a thermostat. After the 4-h hydrolysis, the enzymes were inactivated by heating and holding at $85^{\circ} \mathrm{C}$ for $15 \mathrm{~min}$ followed by centrifugation $\left(9000 \times g, 4^{\circ} \mathrm{C}, 30 \mathrm{~min}\right)$, and the supernatant was freeze-dried to obtain the respective enzymatic protein hydrolysate and stored at $-20^{\circ} \mathrm{C}$. 
Measurement of degree of hydrolysis $(\mathrm{DH})$

The method with $O$-phthalaldehyde (OPA) described by Charoenphun et al. [2013] was used to estimate DH with some modifications. The freshly prepared reagent consisted of $6 \mathrm{mM}$ OPA (dissolved in methanol) and $0.2 \%(v / v) 2$-mercaptoethanol in $50 \mathrm{mM}$ sodium tetraborate containing $1 \%$ $(w / v)$ sodium dodecyl sulphate (SDS). Acid hydrolysis was performed on the FLI using $6 \mathrm{M} \mathrm{HCl}(5 \mathrm{mg} / \mathrm{mL}$ concentration of the FLI in the acid) at $110^{\circ} \mathrm{C}$ for $24 \mathrm{~h}$. A $200 \mu \mathrm{L}$ aliquot of the OPA reagent was added to $5 \mu \mathrm{L}$ of the standard (GlyGly-Gly), protein hydrolysates or acid-hydrolyzed isolate. The mixture was incubated for $100 \mathrm{~s}$ at room temperature and the absorbance was measured at $340 \mathrm{~nm}$ using a microplate reader (Multiskan Thermo Fischer Scientific, Waltham, MA, USA). The DH, defined as the percentage of cleaved peptide bonds, was calculated as follows:

DH $(\%)=\frac{\left(\mathrm{NH}_{2}\right) t_{x}-\left(\mathrm{NH}_{2}\right)_{t o}}{\left(\mathrm{NH}_{2}\right)_{\text {total }}-\left(\mathrm{NH}_{2}\right)_{t o}} \times 100$

where: $\left(\mathrm{NH}_{2}\right) \mathrm{t}_{\mathrm{x}}$ is the number of free amino groups in the protein hydrolysate and $\left(\mathrm{NH}_{2}\right)_{\text {total }}$ is the total number of amino groups in the protein (obtained from acid hydrolysate of FLI), and $\left(\mathrm{NH}_{2}\right)_{\text {to }}$ is the amount of free amino groups of unhydrolyzed FLI.

\section{Membrane ultrafiltration of fluted pumpkin leaf protein hydrolysate}

Based on the bioactive properties, the Alcalase hydrolysate $(\mathrm{AH})$ exhibited superior activities relative to the hydrolysates. As a result of this, AH was fractionated in an Amicon 8400 ultrafiltration stirred cell (Millipore Corp., Billerica, MA, USA) using 1, 3, 5, and $10 \mathrm{kDa}$ molecular cut offs (MWCO) membranes. The Alcalase hydrolysate was passed through a $1 \mathrm{kDa}$ membrane to collect the $<1 \mathrm{kDa}$ permeate while the retentate from the $<1 \mathrm{kDa}$ was passed through the $3 \mathrm{kDa}$ membrane to obtain the $1-3 \mathrm{kDa}$. The retentate from the $3 \mathrm{kDa}$ was passed through a $5 \mathrm{kDa}$ to obtain $3-5 \mathrm{kDa}$ permeates while the retentate from the $5 \mathrm{kDa}$ was finally passed through a $10 \mathrm{kDa}$ membrane to obtain the $5-10 \mathrm{kDa}$ permeate. The final retentate $(>10 \mathrm{kDa})$ and all the membrane permeates were freezedried and stored at $-20^{\circ} \mathrm{C}$.

\section{Amino acid composition}

The amino acid profile of each sample was determined according to the established methods described by Girgih et al. [2011] using a HPLC system after hydrolysis with $6 \mathrm{M} \mathrm{HCl}$. The cysteine and methionine contents were determined after performic acid oxidation while the tryptophan content was determined after alkaline hydrolysis.

\section{Determination of molecular weight distribution}

The molecular weight (MW) distribution of fluted pumpkin leaf protein isolate and hydrolysates was evaluated using the method described by Alashi et al. [2014]. A $1000 \mu \mathrm{L}$ sample aliquot, taken from the sample prepared at $5 \mathrm{mg} / \mathrm{mL}$ concentration in a phosphate buffer, $\mathrm{pH} 7.0$, containing $0.15 \mathrm{M}$ $\mathrm{NaCl}$ was loaded on the AKTA FPLC system (GE Healthcare, Montreal, PQ, Canada) equipped with a Superdex ${ }^{\mathrm{TM}}$
Peptide 10/300 GL column $(10 \times 300 \mathrm{~mm})$ and the elution was carried out at room temperature using a phosphate buffer at $0.5 \mathrm{~mL} / \mathrm{min}$ flow rate. Peptide molecular weight of each peak was estimated by extrapolating sample elution volume to a linear plot of log MW versus elution volume of standard proteins (cytochrome C, $12.38 \mathrm{kDa}$; aprotinin, $6.51 \mathrm{kDa}$; vita$\min \mathrm{B} 12,1.85 \mathrm{kDa}$; glycine, $0.075 \mathrm{kDa}$ ).

\section{Determination of antioxidant properties}

\section{1,1-Diphenyl-2-picrylhydrazine (DPPH) radical scavenging activities}

The method described by Girgih et al. [2011], with little modification, was used to determine the DPPH radical scavenging activities of the samples. The samples were made into solution using $0.1 \mathrm{M}$ sodium phosphate buffer, $\mathrm{pH}$ 7.0, that contained $1 \%(\mathrm{v} / \mathrm{v})$ Triton-X and prepared to a final concentration of $0.0156-1.0 \mathrm{mg} / \mathrm{mL}$. A $100 \mu \mathrm{M}$ DPPH radical concentration was prepared using $95 \%$ methanol. A $0.1 \mathrm{~mL}$ aliquot of each sample and $0.1 \mathrm{~mL}$ of the DPPH radical solution was pipetted into a 96-well plate. The mixture was incubated in the dark for $30 \mathrm{~min}$ at room temperature. The buffer and the reduced glutathione (GSH) served as the blank and positive control, respectively. After incubation, the absorbance was measured at $517 \mathrm{~nm}$ using a microplate reader. The percentage DPPH radical scavenging activity was calculated using Equation (2):

$$
\begin{gathered}
D P P H \text { radical scavenging activity }(\%)= \\
=\frac{(A 1-A 2)}{A 1} \times 100
\end{gathered}
$$

where: A1 and A2, are absorbance of the blank and sample, respectively. The effective concentration that scavenged $50 \%$ of the free radicals $\left(\mathrm{EC}_{50}\right)$ was calculated for each sample by non-linear regression from a plot percent DPPH radical scavenging activity versus sample concentration $(\mathrm{mg} / \mathrm{mL})$.

\section{Superoxide radical scavenging activity}

The method described by Xie et al. [2008] was used to determine superoxide radical scavenging activity (SRSA) of the FLI, hydrolysates, AH fractions, and GSH as the standard. Each of the samples was dissolved in $50 \mathrm{mM}$ Tris- $\mathrm{HCl}$ buffer, pH 8.3, containing $1 \mathrm{mM}$ EDTA to concentrations between 0.25 and $1.5 \mathrm{mg} / \mathrm{mL}$. The sample $(80 \mu \mathrm{L})$ was transferred into a clear bottom microplate well while $80 \mu \mathrm{L}$ of buffer was added to the blank well. This was followed by the addition of $40 \mu \mathrm{L}$ of $1.5 \mathrm{mM}$ pyrogallol (dissolved in $10 \mathrm{mM}$ $\mathrm{HCl}$ ) into each well in the dark, and the change in the rate of reaction was measured immediately at room temperature over a period of $4 \mathrm{~min}$ (1 min interval) using a microplate reader at a wavelength of $420 \mathrm{~nm}$. The SRSA was calculated using the Equation 3:

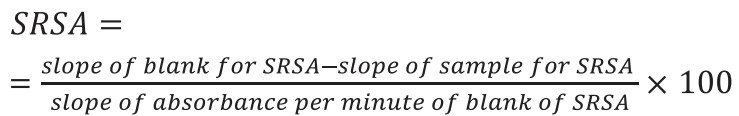


The $\mathrm{EC}_{50}$ was calculated for each sample by non-linear regression from a plot of percent SRSA versus sample concentration $(\mathrm{mg} / \mathrm{mL})$.

\section{Hydroxyl radical scavenging activity}

The hydroxyl radical scavenging activity (HRSA) of the samples was determined by a modified method of Ajibola et al. [2011]. The samples $(0.1-4 \mathrm{mg} / \mathrm{mL})$ and 1,10 phenanthroline $(3 \mathrm{Mm})$ were dissolved in $0.1 \mathrm{M}$ phosphate buffer (pH 7.4) separately. Also, $3 \mathrm{mM} \mathrm{FeSO}$ and $0.01 \%(w / v)$ hydrogen peroxide were each separately dissolved in distilled water. The mixture was incubated for $1 \mathrm{~h}$ at room temperature and centrifuged $(3500 \times g$, for $30 \mathrm{~min})$. To a 96-well plate, $50 \mu \mathrm{L}$ of the sample or GSH was first pipetted, followed by $50 \mu \mathrm{L}$ of each of the 1,10-phenanthroline and $\mathrm{FeSO}_{4}$ solutions. The reaction was initiated by adding $50 \mu \mathrm{L}$ of hydrogen peroxide to the well that was then covered, incubated at $37^{\circ} \mathrm{C}$ for $1 \mathrm{~h}$, and shaken constantly. The blank was prepared in a similar manner as the sample but was made up of $50 \mu \mathrm{L}$ of the phosphate buffer in place of the sample. The absorbance of the colored reaction mixtures was measured at 10 min intervals for $1 \mathrm{~h}$ in a microplate reader at a wavelength of $536 \mathrm{~nm}$. The reaction rate $(\Delta \mathrm{A} / \mathrm{min})$ was then used to evaluate the HRSA value as follows:

$H R S A=\frac{\Delta \mathrm{A} / \mathrm{min} \text { of blank }-\Delta \mathrm{A} / \mathrm{min} \text { of sample }}{\Delta \mathrm{A} / \mathrm{min} \text { of blank }} \times 100$

The effective concentration that scavenged 50\% of hydroxyl radicals was calculated for each sample using a non-linear regression from a plot of HRSA (\%) activity versus sample concentration $(\mathrm{mg} / \mathrm{mL})$.

\section{Ferric reducing antioxidant power}

The modified method described by Benzie \& Strain [1996] was used determine the ferric reducing antioxidant power (FRAP) of the samples. The FRAP working reagents were prepared as follows: acetate buffer ( $300 \mathrm{mM}$ at $\mathrm{pH} 3.6)$; 2,4,6-tri-(2-pyridyl)-1,3,5-triazine $(10 \mathrm{mM}) ;$ and $\mathrm{FeCl}_{3}$ $(20 \mathrm{mM})$ were mixed in the ratio of $5: 1: 1(\mathrm{v} / \mathrm{v} / \mathrm{v})$ to obtain a straw-colored solution and the temperature was raised to $37^{\circ} \mathrm{C}$. The samples were dissolved in water to the final concentration of $0.167 \mathrm{mg} / \mathrm{mL}$. About $40 \mu \mathrm{L}$ of the sample solution and $200 \mu \mathrm{L}$ of FRAP reagent were pipetted into a clear 96-well microplate and the absorbance of the mixture was read at $593 \mathrm{~nm}$. The ferric ion reducing ability of the samples were extrapolated from the calibration curve obtained from iron (II) sulfate heptahydrate $\left(\mathrm{FeSO}_{4} \times 7 \mathrm{H}_{2} \mathrm{O}\right)$ prepared at concentrations between 0.025 and $0.25 \mathrm{mM}$ and presented as $\mathrm{Fe}^{2+}(\mathrm{mM})$.

\section{Metal chelating activity}

The metal chelating activity (MCA) of the samples was evaluated using the $\mathrm{FeCl}_{2} /$ ferrozine method described by Xie et al. [2008]. The samples and the standard (glutathione) were dissolved in distilled water to concentrations between 1 and $5 \mathrm{mg} / \mathrm{mL}$ and water was used as blank. One thousand microliters of the sample, standard or blank was transferred into different test-tubes and $50 \mu \mathrm{L}$ of $\mathrm{FeCl}_{2}(2 \mathrm{mM})$ was added, followed by $1.85 \mathrm{~mL}$ of distilled water, and then $100 \mu \mathrm{L}$ of $5 \mathrm{mM}$ ferrozine. The mixture was well vortexed and incubated for $10 \mathrm{~min}$ at room temperature. The reaction mixture $(200 \mu \mathrm{L})$ was subsequently transferred from the reaction tube into a 96-well plate and absorbance values for the blank (Ab) and samples (As) were measured at $562 \mathrm{~nm}$ using a microplate reader. The MCA was determined using Equation (5):

Metal chelating activity $(\%)=\frac{(A b-A s)}{A b} \times 100$

The effective concentration that chelated $50 \%$ of the metals $\left(\mathrm{EC}_{50}\right)$ was calculated for each sample by non-linear regression from a plot of metal chelating activity (\%) versus sample concentration $(\mathrm{mg} / \mathrm{mL})$.

\section{Inhibition of linoleic acid oxidation}

The inhibitory properties of the protein samples against linoleic acid oxidation were evaluated following the method described by He et al. [2013]. Sodium phosphate buffer (0.1 M, pH 7.0) was used to dissolve the samples and GSH (standard) to give sample concentration of $0.25 \mathrm{mg} / \mathrm{mL}$, and then the sample was centrifuged. About $1 \mathrm{~mL}$ of the sample supernatant or blank (phosphate buffer) was mixed with $1 \mathrm{~mL}$ of linoleic acid (50 mM linoleic acid dissolved in 95\% ethanol). The mixture was incubated at $60^{\circ} \mathrm{C}$ and the degree of color changes was measured after $24 \mathrm{~h}$ for seven days. Each day, the reaction tube contained $100 \mu \mathrm{L}$ aliquot of the assay mixture, in addition to $4.7 \mathrm{~mL}$ of $75 \%(v / v)$ ethanol, $100 \mu \mathrm{L}$ of $30 \%(w / v)$ ammonium thiocyanate, and $100 \mu \mathrm{L}$ of $0.02 \mathrm{M}$ ferric chloride dissolved in $1 \mathrm{M} \mathrm{HCl}$. After the mixture was incubated for $3 \mathrm{~min}, 200 \mu \mathrm{L}$ was transferred into a clear-bottom 96-well plate and the absorbance was measured at $500 \mathrm{~nm}$ using a microplate reader. An increase in the absorbance value suggested a high level of linoleic acid oxidation.

\section{Inhibition of angiotensin-converting enzyme}

The in vitro inhibitory properties of the FLI, hydrolysates, and $\mathrm{AH}$ fractions against the ACE (purchased from Sigma-Aldrich, St. Louis, MO, USA) were evaluated following the method described by Udenigwe et al. [2009], involving the use of $\mathrm{N}$-[3-(2-furyl)acryloyl]-Phe-Gly-Gly (FAPPG) and Tris- $\mathrm{HCl}$ buffer. Briefly, $1 \mathrm{~mL}$ of $0.5 \mathrm{mM}$ FAPGG (dissolved in $50 \mathrm{mM}$ Tris- $\mathrm{HCl}$ buffer containing $0.3 \mathrm{M} \mathrm{NaCl}, \mathrm{pH} 7.5$, and kept at $37^{\circ} \mathrm{C}$ ) was mixed with $20 \mu \mathrm{L}$ of ACE (final activity of $20 \mathrm{mU}$ ) and $200 \mu \mathrm{L}$ of the samples $(0.2$ to $3 \mathrm{mg} / \mathrm{mL}$ assay concentration) dissolved in the Tris- $\mathrm{HCl}$ buffer. The rate of decrease in absorbance at $345 \mathrm{~nm}$ was recorded for $2 \mathrm{~min}$ at room temperature. Tris- $\mathrm{HCl}$ buffer served as the assay blank. ACE activity was expressed as the change in the rate of reaction $(\Delta \mathrm{A} / \mathrm{min})$ and inhibitory activity was determined using Equation 6:

\section{ACE ibhibition $=$ \\ $=\frac{\Delta A / \min (\text { blank })-\Delta A / \min (\text { sample })}{\Delta A / \min (\text { blank })} \times 100$}

where: $(\Delta \mathrm{A} / \mathrm{min})($ blank $)$ and $(\Delta \mathrm{A} / \mathrm{min})($ sample $)$ are $\mathrm{ACE}$ activities in the absence and presence of samples, respectively. The concentration that inhibited $50 \%$ of the ACE 
$\left(\mathrm{IC}_{50}\right)$ was calculated for each sample by non-linear regression from a plot of ACE activity (\%) versus sample concentration $(\mathrm{mg} / \mathrm{mL})$.

\section{Inhibition of $\alpha$-amylase}

The porcine $\alpha$-amylase inhibitory activity of the samples was evaluated using the 3,5-dinitrosalicylic acid (DNSA) method described by Kwon et al. [2008]. The samples and standard (acarbose) were dissolved using phosphate buffer $(0.02 \mathrm{M}, \mathrm{pH} 6.9$ containing $6 \mathrm{mM} \mathrm{NaCl})$ to a final concentration of $200-500 \mu \mathrm{g} / \mathrm{mL}$ and $1-9 \mu \mathrm{g} / \mathrm{mL}$ for the samples and standard, respectively. $\alpha$-Amylase (purchased from Sigma-Aldrich (St. Louis, MO, USA) was also dissolved in phosphate buffer $(0.02 \mathrm{M}, \mathrm{pH} 6.9$ containing $6 \mathrm{mM} \mathrm{NaCl}$ ) to a final concentration of $1 \mathrm{mg} / \mathrm{mL}$. One hundred microliters of the samples or the standard were mixed with $100 \mu \mathrm{L}$ of $\alpha$-amylase (200 units/mg) in a reaction tube and pre-incubated to $25^{\circ} \mathrm{C}$. Two hundred microliters of a starch solution (1\%, prepared in $0.02 \mathrm{M}$ phosphate buffer, pH 6.9 containing $6 \mathrm{mM} \mathrm{NaCl}$ ) were added to the assay mixture and incubated for $10 \mathrm{~min}$ at room temperature. The reactions were halted after the mixture was incubated in boiling water for $5 \mathrm{~min}$. Then, $1000 \mu \mathrm{L}$ DNSA was added and the mixture was cooled. Two hundred microliters of the mixture were pipetted into the 96-well microplate after diluting to the ratio of 1:5 with double distilled water. The absorbance was then measured with a microplate reader at $540 \mathrm{~nm}$. The percentage inhibition was then determined using Equation (7):

$\alpha-$ Amylase inhibition $(\%)=$ $\frac{(\text { Absorbance of control-(Absorbance of sample-Absorbance of sample blank }))}{\text { Absorbance of control }} \times 100$

\section{Inhibition of $\boldsymbol{\alpha}$-glucosidase}

The yeast $\alpha$-glucosidase and $p$-nitrophenyl- $\alpha$-D-glucopyranoside (pNPG) were used to determine the inhibitory activity of the samples against $\alpha$-glucosidase [Kim et al., 2004]. The samples, the standard (acarbose), and $\alpha$-glucosidase enzyme (purchased from Sigma-Aldrich, St. Louis, MO, USA) were dissolved using a phosphate buffer $(0.1 \mathrm{M}, \mathrm{pH} 6.9)$ to final concentrations of $1-6 \mathrm{mg} / \mathrm{mL}$, $0.0312-0.25 \mathrm{mg} / \mathrm{mL}$, and $1 \mathrm{mg} / \mathrm{mL}$ for the samples, acarbose and $\alpha$-glucosidase respectively. Exactly $100 \mu \mathrm{L}$ of the sample or the standard was added to $50 \mu \mathrm{L}$ of the enzyme (200 units/mg). After pre-incubating for $20 \mathrm{~min}$ at $37^{\circ} \mathrm{C}$, $100 \mu \mathrm{L}$ of pNPG $(5 \mathrm{mM}$, dissolved in $0.1 \mathrm{M}$ phosphate buffer, $\mathrm{pH}$ 6.9) was added to a 96 -well microplate. The mixture was incubated for $10 \mathrm{~min}$ at $37^{\circ} \mathrm{C}$ and the absorbance was read with a microplate reader at $405 \mathrm{~nm}$ for $30 \mathrm{~min}$ at the interval of $1 \mathrm{~min}$. The percentage inhibitory activity was evaluated using Equation (8):

\footnotetext{
$\alpha-$ Glucosidase inhibition $(\%)=$

$=\frac{(\text { final absorbance of blank-(final absorbance of sample })}{\text { final absorbance of blank }} \times 100$
}

\section{Mass spectrometry and identification of peptide sequences}

Peptide sequences present in the protein hydrolysates were identified using the method of Malomo \& Aluko [2019]. Sample solutions were diluted to $10 \mathrm{ng} / \mu \mathrm{L}$ using aqueous formic acid $(0.1 \%, v / v)$ and passed through a $0.2 \mu \mathrm{m}$ filter. Then, $10 \mu \mathrm{L}$ of the filtrate was infused into an Absciex QTRAP ${ }^{\circledR}$ 6500 mass spectrometer (Absciex Ltd., Foster City, CA, USA) coupled with an electrospray ionization source. Operating conditions were as previously described: $3.5 \mathrm{kV}$ ion spray voltage at $150^{\circ} \mathrm{C}$, and $30 \mu \mathrm{L} / \mathrm{min}$ flow rate for $3 \mathrm{~min}$ in the positive ion mode with $2000 \mathrm{~m} / \mathrm{z}$ scan maximum. The peptide sequences were obtained according to The Uniprot Consortium [2019] using the published primary sequences of Telfairia occidentalis Rubisco protein (Entry name $=$ A5X4F4_9ROSI) at mass tolerance of $+0.05 \mathrm{Da}$.

\section{Statistical analysis}

The experiments were carried out in triplicate determinations. Data were subjected to the analysis of variance using the statistical package for social sciences software, version 18. The statistical significance of difference between mean values of the data were chosen at $\mathrm{p}<0.05$ level using the Duncan Multiple Range Test.

\section{RESULTS AND DISCUSSION}

\section{Degree of hydrolysis (DH)}

After a 4-h enzymatic hydrolysis of FLI, the DH ranged between 16.37 and $20.66 \%$. Chymotrypsin hydrolysate $(\mathrm{CH})$ had the highest DH $(20.66 \pm 0.37 \%)$. This value was not different significantly $(\mathrm{p} \geq 0.05)$ from the $\mathrm{DH}$ of $20.53 \pm 0.21 \% \mathrm{ob}-$ tained for trypsin hydrolysate (TH) and $19.06 \pm 0.23 \%$ for pepsin hydrolysate $(\mathrm{PH})$ but significantly $(\mathrm{p}<0.05)$ higher than the value $(16.37 \pm 0.42 \%)$ obtained for Alcalase hydrolysate $(\mathrm{AH})$. This may suggest that the peptide bonds of the protein (FLI) are more accessible to chymotrypsin, trypsin, and pepsin enzymes, since the DH depends on the number of broken bonds, which also reflects the enzyme specificity during digestion [Filho et al., 2020]. Muhamyankaka et al. [2013] reported 6-14\% DH of pumpkin seeds protein hydrolysates, values that are lower than obtained in the current work. The differences in DH values may suggest variations in the amino acid sequence of the proteins (pumpkin seed vs. leaf), which will affect the number of peptide bonds broken by the proteases.

\section{Amino acid composition}

Table 1 shows that the protein hydrolysates had higher contents of aspartic, glutamic, proline, valine, and lysine amino acids, when compared to FLI. The essential amino acid contents were higher than the 32.14 to $34.81 \%$ earlier reported for pumpkin seed protein hydrolysates [Muyamyyankaka et al., 2013], which indicates that the samples are good sources of high-quality protein. All the samples had high (>35\%) contents of hydrophobic amino acids, which were higher in the hydrolysates compared to FLI. The hydrophobic amino acid content is important due to the potential for increased peptide solubility in hydrophobic environments, which can lead to enhanced antioxidant activities [Rajapakse et al., 2005; 
TABLE 1. Amino acid composition (\%) of fluted pumpkin leaf protein and hydrolysates*.

\begin{tabular}{|c|c|c|c|c|c|}
\hline Amino acid & FLI & $\mathrm{AH}$ & $\mathrm{CH}$ & $\mathrm{PH}$ & $\mathrm{TH}$ \\
\hline Aspartic acid/asparagine & 10.28 & 11.73 & 11.19 & 11.00 & 11.32 \\
\hline Threonine & 4.22 & 2.21 & 2.90 & 4.05 & 2.71 \\
\hline Serine & 5.22 & 2.91 & 3.74 & 5.24 & 3.45 \\
\hline Glutamic acid/glutamine & 11.08 & 14.94 & 12.74 & 14.36 & 13.25 \\
\hline Proline & 4.30 & 5.03 & 5.03 & 5.74 & 4.89 \\
\hline Glycine & 5.22 & 4.72 & 4.79 & 5.12 & 4.81 \\
\hline Alanine & 6.75 & 6.42 & 6.59 & 6.69 & 6.62 \\
\hline Cysteine & 1.66 & 1.10 & 0.91 & 0.96 & 0.84 \\
\hline Valine & 5.73 & 7.33 & 6.46 & 6.66 & 6.53 \\
\hline Methionine & 2.22 & 1.79 & 1.97 & 1.21 & 1.73 \\
\hline Isoleucine & 4.72 & 5.78 & 5.32 & 4.53 & 5.50 \\
\hline Leucine & 9.04 & 9.30 & 9.81 & 8.08 & 9.14 \\
\hline Tyrosine & 4.35 & 2.66 & 2.69 & 2.70 & 2.14 \\
\hline Phenylalanine & 5.66 & 5.61 & 6.27 & 4.77 & 5.22 \\
\hline Histidine & 3.53 & 3.07 & 3.16 & 3.44 & 3.04 \\
\hline Lysine & 6.92 & 7.08 & 7.18 & 7.25 & 8.33 \\
\hline Arginine & 6.88 & 6.43 & 7.24 & 6.94 & 9.04 \\
\hline Tryptophan & 2.21 & 1.89 & 2.00 & 1.24 & 1.42 \\
\hline BCAA & 19.49 & 22.41 & 21.59 & 19.27 & 21.17 \\
\hline HAA & 37.98 & 40.37 & 39.97 & 38.03 & 39.22 \\
\hline AAA & 12.22 & 10.16 & 10.96 & 8.71 & 8.78 \\
\hline PCAA & 17.33 & 16.58 & 17.58 & 17.63 & 20.41 \\
\hline NCAA & 30.80 & 31.79 & 30.57 & 34.65 & 30.73 \\
\hline SCAA & 3.88 & 2.89 & 2.88 & 2.17 & 2.57 \\
\hline EAA & 44.25 & 44.06 & 45.07 & 41.23 & 43.62 \\
\hline
\end{tabular}

*FLI, protein isolate; $\mathrm{AH}$, Alcalase hydrolysate; $\mathrm{CH}$, chymotrypsin hydrolysate; $\mathrm{PH}$, pepsin hydrolysate; TH, trypsin hydrolysate. BCAA: branched-chain amino acids (valine, leucine, isoleucine); HAA: hydrophobic amino acids (proline, glycine, alanine, leucine, isoleucine, valine, methionine); AAA: aromatic amino acids (tyrosine, phenylalanine, tryptophan); PCAA positively-charged amino acids (arginine, lysine, histidine; NCAA: negatively-charged amino acids (aspartic acid/asparagine, glutamic acid/glutamine, serine, threonine); SCAA: sulfur-containing amino acids (cysteine and methionine); EAA: Essential amino acids (valine, leucine, isoleucine, phenylalanine, histidine, tryptophan, methionine, lysine, threonine).

Zhu et al., 2006]. The content of branched-chain amino acids (BCAAs) was also higher in hydrolysates than in FLI with the exception of PH. The presence of BCAAs is reported to be important for enhanced ACE-inhibitory activity of peptides. Increased levels of negatively charged and positively charged amino acids were observed only for $\mathrm{PH}$ and $\mathrm{TH}$, respectively. Amino acids with negative charges contain excess electrons, which may contribute to an increase in the free radical quenching ability of antioxidant peptides. However, there were decreases in aromatic and sulfur-containing amino acids, which have also been suggested to contribute to increased antioxidant activities [Udenigwe \& Aluko, 2012].

\section{Peptide sequencing}

Amino acid sequences of identified peptides, the observed mass/charge and the calculated mases are shown in Table 2. Based on the protein database, six, seven, eleven, and four peptides were identified in Alcalase, chymotrypsin, pepsin, and trypsin hydrolysates, respectively. $\mathrm{CH}$ contained a higher number of dipeptides (5 out of 7 peptides identified) when compared with the other protein hydrolysates. This is consistent with the DH of the hydrolysates in this study, where $\mathrm{CH}$ had the highest value. The presence of shorter peptides such as the dipeptides may suggest greater advantages to interact with and neutralize free radicals more effectively to inhibit propagation. In addition, all the identified peptides have molecular weights $<500 \mathrm{Da}$ and this may enhance the ease of absorption of the peptides from the gastrointestinal tract and improve in vivo activities [Malomo \& Aluko, 2019]. Alcalase and chymotrypsin hydrolysates shared three (PGV, GVP, and RP) common peptides (2 tripeptides and 1 dipeptide) while pepsin and trypsin hydrolysates showed two (STGT and FKA) similar peptides. The similarity in some of the peptides identified in the hydrolysates suggests that the catalytic activities of the enzymes can be well compared. With the exception of HAVI, all the peptides identified from $\mathrm{AH}$ and $\mathrm{CH}$ contained proline while BCAAs (L, I, V) were also present in most of the peptides. Most of the peptides were mainly composed of either hydrophobic or branched chain amino acids, which may have implications in their bioactivities. For instance, Chen et al. [2012] reported that the presence of glycine in egg-white peptide contributed to the antioxidant properties of the hydrolysate due proton donating ability of this amino acid. A previous report by Mirzaei et al. [2016] showed that the presence of hydrophobic amino acids such as proline in the peptide sequence obtained from Saccharomyces cerevisiae facilitated the scavenging of free radical species and the quenching of singlet oxygen.

A previous study has indicated that the dipeptide sequences (RP, VP, PV) have ACE-inhibitory activity [Sentandreu \& Toldrá, 2007] while IP, PI, LP, VF, and FV peptides are dipeptidyl peptidase (DPP)-IV inhibitors in addition to their ACE inhibitory potentials [Lacroix \& Li-Chan, 2012; Sentandreu \& Toldrá, 2007]. Several other dipeptide subsequences that make up tripeptides and tetrapeptides identified in this study have been linked to various bioactivities. For instance, PGV (PG, GV subsequences), GVP (VP and GP subsequences), IEPV (IE, PV or EP subsequences), PLDL (PL, LD or DL subsequences), SSTG (ST and TG subsequences), YIA (YI and IA subsequences), and IAY (IA and AY subsequences) have been reported to function as ACE and DPP-IV inhibitors according to BIOPEP UWM database [http://www.uwm.edu. $\mathrm{pl} /$ biochemia/index.php/pl/biopep]. The peptide subsequences, HA and VI of the identified tetrapeptide HAVI have also been reported to possess renin inhibitory activity [Pihlanto \& Mäkinen, 2017] while KA dipeptide, which is one of the subsequences of FKA, has been reported as DPP-III inhibitor [Dhanda et al., 2008]. 
TABLE 2. Amino acid sequences of peptides identified in the enzymatic hydrolysates of fluted pumpkin leaf protein isolate.

\begin{tabular}{|c|c|c|c|}
\hline $\begin{array}{c}\text { Observed } \\
\text { molecular } \\
\text { weight }(\mathrm{Da})\end{array}$ & $\begin{array}{c}\text { Calculated } \\
\text { molecular } \\
\text { weight (Da) }\end{array}$ & $\begin{array}{c}\text { Peptide } \\
\text { sequence }\end{array}$ & Location* \\
\hline \multicolumn{4}{|c|}{ Alcalase hydrolysate $(\mathrm{AH})$} \\
\hline 272.200 & 272.160 & PGV & f30-32, 356-358 \\
\hline 272.200 & 272.160 & GVP & f31-33, 245-247 \\
\hline 272.200 & 272.172 & $\mathrm{RP}$ & f151-152 \\
\hline 439.300 & 439.266 & HAVI & $\mathrm{f} 282-285$ \\
\hline 457.300 & 457.266 & IEPV & F71-74 \\
\hline 457.300 & 457.266 & PLDL & F883-91 \\
\hline \multicolumn{4}{|c|}{ Chymotrypsin hydrolysate $(\mathrm{CH})$} \\
\hline 229.200 & 229.155 & PL & f88-89, 152-153 \\
\hline 229.200 & 229.155 & PI & f247-248 \\
\hline 229.200 & 229.155 & IP & f124-125 \\
\hline 229.200 & 229.155 & LP & f355-356, 359-360 \\
\hline 272.200 & 272.160 & PGV & $\mathrm{f} 30-32,356-358$ \\
\hline 272.200 & 272.160 & GVP & f31-33, 245-247 \\
\hline 272.200 & 272.172 & $\mathrm{RP}$ & f151-152 \\
\hline \multicolumn{4}{|c|}{ Pepsin hydrolysate (PH) } \\
\hline 215.100 & 215.139 & $\mathrm{VP}$ & $\mathrm{f} 32-33,246-247$ \\
\hline 215.100 & 215.139 & PV & f73-74, 360-361 \\
\hline 351.200 & 351.151 & SSTG & f $45-48$ \\
\hline 351.200 & 351.166 & FQG & f132-134 \\
\hline 351.200 & 351.166 & QFG & f385-387 \\
\hline 351.200 & 351.166 & GFK & f110-112 \\
\hline 365.200 & 365.167 & STGT & f $46-49$ \\
\hline 365.200 & 365.218 & FKA & f111-113 \\
\hline 365.200 & 365.202 & YIA & f81-83 \\
\hline 365.200 & 365.202 & IAY & f82-84 \\
\hline 365.200 & 365.202 & AIY & f208-210 \\
\hline \multicolumn{4}{|c|}{ Trypsin hydrolysate (TH) } \\
\hline 265.200 & 265.155 & $\mathrm{VF}$ & f108-109, 239-240 \\
\hline 265.200 & 265.155 & $\mathrm{FV}$ & f329-330, 337-338 \\
\hline 365.200 & 365.167 & STGT & f $46-49$ \\
\hline 365.200 & 365.218 & FKA & f111-113 \\
\hline
\end{tabular}

*Within the primary structure of Telfairia occidentalis Rubisco; $\mathrm{f}=$ fragment.

\section{Molecular weight distribution}

Size exclusion chromatography was used to estimate the molecular weight distribution of fluted pumpkin leaf protein isolate and hydrolysates, as shown in Figure 1. The molecular weight of the hydrolysates was mainly be- tween 2.1 and $7.2 \mathrm{kDa}$, which was lower than the molecular weight of FLI $(19.11 \mathrm{kDa})$. The results show that the FLI was degraded to lower molecular weights by the hydrolyzing enzymes. A previous study on alfalfa leaf hydrolysate reported a peptide molecular weight range of 0.2 to $1.9 \mathrm{kDa}$ [Xie et al., 2008]. The estimated molecular weight of PH main peak that eluted early $(\sim 12 \mathrm{~min})$ was $7.2 \mathrm{kDa}$, which suggests the presence of bigger peptides when compared to the other protein hydrolysates with longer elution times. The findings from these results showed that the hydrolysates have varying peptide molecular weights, which is consistent with the fact that the enzymes differ in protease specificity. This variation in molecular weights of the hydrolysates with respect to the hydrolyzing enzymes is expected to influence the functional and bio-active effects of the hydrolysates because these properties are dependent on the chain length of peptides closely correlated with their molecular weight [Wasswa et al., 2007]. The smaller average peptide molecular weight of $\mathrm{TH}$, $\mathrm{AH}$, and $\mathrm{CH}$ is important because of the potential for escaping further enzyme degradation in the gastro-intestinal tract and improving absorption into blood circulation [Horton et al., 2002].

\section{Antioxidant properties}

\section{DPPH radical scavenging activity (DRSA)}

The DRSA is based on a decolorization assay that measures the capacity of antioxidants to directly react with the DPPH radical by monitoring its absorbance at $517 \mathrm{~nm}$. It is a stable organic nitrogen-centered free radical with a dark purple color but becomes colorless when reduced to its non-radical form by an electron-donating compound, which enables estimating antioxidant capacity [Saidi et al., 2014]. The DRSA values of fluted pumpkin leaf isolate and hydrolysate are shown in Table 3 . The $\mathrm{EC}_{50}$ values of the protein

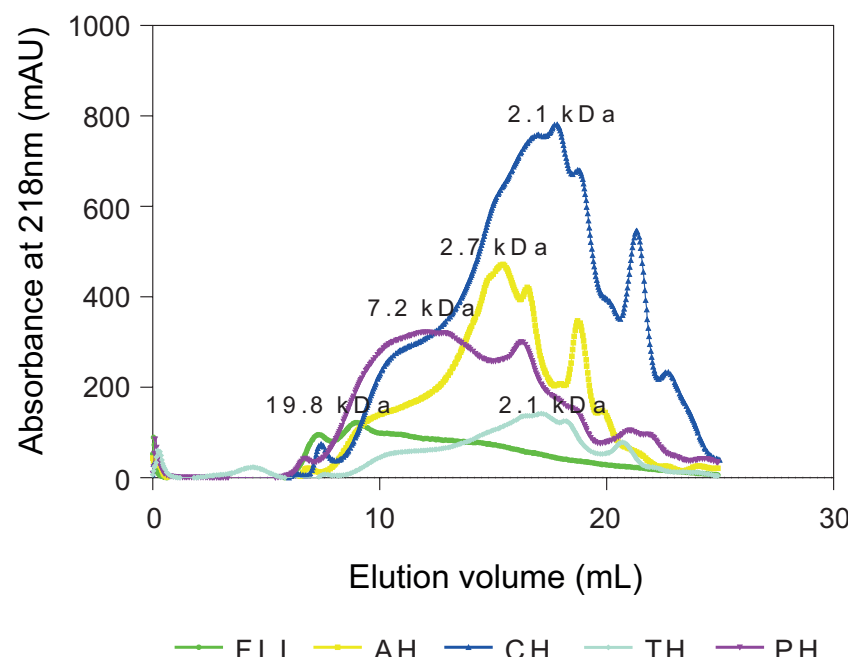

FIGURE 1. Comparative gel-permeation chromatograms of the fluted pumpkin leaf protein isolate (FLI) and Alcalase $(\mathrm{AH})$, chymotrypsin $(\mathrm{CH})$, pepsin $(\mathrm{PH})$, and trypsin $(\mathrm{TH})$ hydrolysates after passage through a Superdex Peptide12 10/300 GL column. Inserted values indicate estimated molecular weights. 
TABLE 3. $\mathrm{EC}_{50}(\mathrm{mg} / \mathrm{mL})$ determined for antioxidant activities and $\mathrm{IC}_{50}(\mathrm{mg} / \mathrm{mL})$ determined for ACE-inhibitory property of fluted pumpkin leaf protein isolate, hydrolysates, and Alcalase hydrolysate ultrafiltration peptide fractions.

\begin{tabular}{|c|c|c|c|c|c|}
\hline & $\begin{array}{l}\text { DPPH radical } \\
\text { scavenging }\end{array}$ & $\begin{array}{l}\text { Superoxide radical } \\
\text { scavenging }\end{array}$ & $\begin{array}{c}\text { Hydroxyl radical } \\
\text { scavenging }\end{array}$ & Metal chelation & ACE inhibition \\
\hline \multicolumn{6}{|c|}{ Hydrolysates } \\
\hline GSH & $0.237 \pm 0.019^{e}$ & $0.785 \pm 0.008^{c}$ & $0.668 \pm 0.023^{\mathrm{d}}$ & $4.961 \pm 0.016^{\mathrm{a}}$ & - \\
\hline FLI & $0.825 \pm 0.029^{a}$ & $0.899 \pm 0.002^{\mathrm{b}}$ & $3.259 \pm 0.087^{\mathrm{c}}$ & $4.655 \pm 0.010^{\mathrm{b}}$ & $2.826 \pm 0.099^{a}$ \\
\hline $\mathrm{AH}$ & $0.240 \pm 0.001^{\mathrm{e}}$ & $0.914 \pm 0.009^{b}$ & $5.969 \pm 0.041^{\mathrm{a}}$ & $4.903 \pm 0.032^{\mathrm{a}}$ & $0.675 \pm 0.035^{\mathrm{d}}$ \\
\hline $\mathrm{CH}$ & $0.486 \pm 0.014^{c}$ & $0.939 \pm 0.007^{\mathrm{a}}$ & $3.170 \pm 0.035^{c}$ & $4.894 \pm 0.006^{\mathrm{a}}$ & $0.666 \pm 0.042^{\mathrm{d}}$ \\
\hline PH & $0.602 \pm 0.153^{b}$ & $0.965 \pm 0.003^{\mathrm{a}}$ & $5.260 \pm 0.062^{\mathrm{b}}$ & $4.756 \pm 0.008^{b}$ & $1.432 \pm 0.014^{\mathrm{b}}$ \\
\hline TH & $0.361 \pm 0.009^{\mathrm{d}}$ & $0.873 \pm 0.005^{\mathrm{b}}$ & $3.277 \pm 0.025^{\mathrm{c}}$ & $4.839 \pm 0.016^{\mathrm{ab}}$ & $0.889 \pm 0.011^{\mathrm{c}}$ \\
\hline \multicolumn{6}{|c|}{ AH fractions } \\
\hline$<1 \mathrm{kDa}$ & $0.047 \pm 0.005^{\mathrm{c}}$ & $0.676 \pm 0.095^{\mathrm{g}}$ & $0.600 \pm 0.023^{\mathrm{d}}$ & $3.283 \pm 0.074^{b}$ & $0.340 \pm 0.036^{c}$ \\
\hline $1-3 \mathrm{kDa}$ & $0.049 \pm 0.001^{\mathrm{c}}$ & $1.222 \pm 0.012^{c}$ & $1.259 \pm 0.087^{c}$ & $2.914 \pm 0.165^{c}$ & $0.217 \pm 0.004^{\mathrm{d}}$ \\
\hline $3-5 \mathrm{kDa}$ & $0.421 \pm 0.014^{\mathrm{a}}$ & $1.112 \pm 0.074^{\mathrm{d}}$ & $1.713 \pm 0.029^{b}$ & $3.342 \pm 0.088^{\mathrm{b}}$ & $0.372 \pm 0.039^{c}$ \\
\hline $5-10 \mathrm{kDa}$ & $0.053 \pm 0.002^{\mathrm{c}}$ & $1.347 \pm 0.013^{\mathrm{b}}$ & $1.711 \pm 0.083^{\mathrm{b}}$ & $3.441 \pm 0.078^{b}$ & $0.356 \pm 0.069^{c}$ \\
\hline$>10 \mathrm{kDa}$ & $0.054 \pm 0.002^{\mathrm{c}}$ & $1.433 \pm 0.037^{\mathrm{a}}$ & $1.456 \pm 0.064^{c}$ & $3.481 \pm 0.015^{\mathrm{b}}$ & $0.446 \pm 0.038^{b}$ \\
\hline GSH & $0.237 \pm 0.019^{b}$ & $0.785 \pm 0.008^{\mathrm{f}}$ & $0.668 \pm 0.023^{\mathrm{d}}$ & $4.961 \pm 0.016^{\mathrm{a}}$ & - \\
\hline
\end{tabular}

Note: Values are mean $\pm \mathrm{SD}$ of triplicate determination. Values with different superscripts along the same column (separately for hydrolysates and AH fractions) are significantly ( $\mathrm{p}<0.05)$ different from each other. Abbreviations: AH, Alcalase hydrolysate; FLI, fluted pumpkin leaf protein isolate; $\mathrm{CH}$, chymotrypsin hydrolysate; PH, pepsin hydrolysate; TH, trypsin hydrolysate; GSH, reduced glutathione.

hydrolysates were between 0.240 and $0.602 \mathrm{mg} / \mathrm{mL}$, which is significantly lower $(\mathrm{p}<0.05)$ compared to the $0.825 \mathrm{mg} / \mathrm{mL}$ determined for FLI. Therefore, the results suggest that the hydrolysates possess stronger electron donating ability when compared to the protein isolate. The results also reflect the beneficial effect of protein hydrolysis in enhancing the bioactive properties of proteins. These results also revealed that the hydrolysates exhibited different DRSA values, which is consistent with the varied proteolytic specificity of the enzymes used during protein hydrolysis. This is because the release of the peptides and the exposure of the amino acid residues depend on the specificity of the enzymes [Thamnarathip et al., 2016]. A previous work also showed different DRSA values for different enzymatic cotton seed protein hydrolysates [Filho et al., 2020]. Among the protein hydrolysates, Alcalase hydrolysate $(\mathrm{AH})$ had stronger DRSA when compared to the other hydrolysates, which may be due to the higher contents of glutamine, valine, and isoleucine (Table 1) and this was the basis for separating Alcalase hydrolysate (AH) into lower molecular weight fractions using ultrafiltration membrane process.

The DRSA $\mathrm{EC}_{50}$ values for the $\mathrm{AH}$ ultrafiltration peptide fractions are shown in Table 3 . With the exception of 3-5 kDa peptides, the peptide fractions had similar DRSA values. The DRSA EC ${ }_{50}$ values of $<1 \mathrm{kDa}(0.047 \mathrm{mg} / \mathrm{mL}), 1-3 \mathrm{kDa}$ $(0.049 \mathrm{kDa})$, and $5-10 \mathrm{kDa}(0.053 \mathrm{mg} / \mathrm{mL})$ were significantly $(p<0.05)$ lower than those of the parent hydrolysate $(0.240 \mathrm{mg} / \mathrm{mL})$ and the $\mathrm{GSH}$, the physiological peptide $(0.261 \mathrm{mg} / \mathrm{mL})$. The results showed $<1 \mathrm{kDa}$ peptide fraction exhibited stronger electron donating ability when compared to the other fractions, which may be related to the small peptide size, which enhanced interactions with the DPPH free radical. The results showing that the $<1 \mathrm{kDa}$ had stronger DRSA than the other peptide fractions are consistent with previous works on perilla seed hydrolysate [Park \& Yoon, 2019] and pigeon pea hydrolysate [Olagunju et al., 2018] peptide fractions.

\section{Superoxide radical scavenging activity (SRSA)}

The superoxide is usually unable to initiate lipid peroxidation without the presence of other free radicals. In addition to its ability to destroy cellular biopolymers, the superoxide radical may also engage in reactions that lead to the production of hydrogen peroxide $\left(\mathrm{H}_{2} \mathrm{O}_{2}\right)$ and the highly toxic hydroxyl radical [Jamdar et al., 2012]. As shown in Table 3, the SRSA $\mathrm{EC}_{50}$ values for the protein hydrolysates were between 0.873 and $0.965 \mathrm{mg} / \mathrm{mL}$, which are significantly $(\mathrm{p}<0.05)$ higher than the $0.785 \mathrm{mg} / \mathrm{mL}$ determined for GSH. This suggests that the hydrolysates had weaker SRSA than GSH. The results suggest that enzymatic hydrolysis did not significantly enhance the SRSA of the hydrolysates, as evidenced in the data whereby the $\mathrm{EC}_{50}$ value obtained for FLI $(0.899 \mathrm{mg} / \mathrm{mL})$ was significantly $(\mathrm{p}>0.05)$ lower than the respective values determined for $\mathrm{CH}$ and $\mathrm{PH}$. The SRSA of $\mathrm{AH}$ peptide fractions is shown in Table 3. The parent hydrolysate $(\mathrm{AH})$ exhibited significantly $(\mathrm{p}<0.05)$ stronger SRSA than the $>1 \mathrm{kDa}$ peptide fractions. The results indicate that with exception of the $<1 \mathrm{kDa}$ peptides, strong peptide synergistic interactions within the protein hydrolysate were weakened after membrane separation. The strong SRSA of $<1 \mathrm{kDa}$ peptides may be due to the small size, which may have favored 
increased interactions with the free radical as previously reported for pigeon pea seed peptide fractions [Olagunju et al., 2018].

\section{Hydroxyl radical scavenging activity (HRSA)}

The hydroxyl radical is one of the most reactive species generated by biological systems, which is mainly generated in vivo by many reactions such as Fenton, superoxide-dependent, and the Haber-Weiss. The hydroxyl radical exerts cellular oxidative damage, which may cause several chronic diseases [Jia et al., 2013]. Therefore, scavenging this radical would reduce the risk for oxidative deterioration of tissues and associated negative effects on human health. The HRSA values for protein isolate and hydrolysates are shown in Table 3. The values showed that the protein hydrolysates had $\mathrm{EC}_{50}$ between 3.170 and $5.969 \mathrm{mg} / \mathrm{mL}$ while the protein isolate had $\mathrm{EC}_{50}$ at $3.259 \mathrm{mg} / \mathrm{mL}$, suggesting that only the Alcalase and pepsin hydrolysates were less potent when compared with the protein isolate. There was no significant difference $(\mathrm{p}>0.05)$ in the HRSA of FLI, TH, and CH. Jia et al. [2013] reported that high contents of hydrophobic amino acids played an important role in the HRSA of mussel protein hydrolysates. The variations in HRSA of the protein hydrolysates may be related to differences in the proteolytic specificities of the enzymes used for digestion.

The HRSA $\mathrm{EC}_{50}$ values of $\mathrm{AH}$ peptide fractions were between 0.600 and $1.713 \mathrm{mg} / \mathrm{mL}$ (Table 3). The separated fractions showed higher radical quenching ability than the parent hydrolysate $(\mathrm{AH})$, which suggests that ultrafiltration membrane separation enhanced the HRSA of the resulting peptides. This may be due to reduced antagonistic interactions between the peptides after membrane ultrafiltration separation. The results are consistent with an earlier report on rapeseed hydrolysates where the peptide fractions showed superior HRSA than the unfractionated hydrolysate [He et al., 2013]. The $<1 \mathrm{kDa}$ peptide fraction possessed significantly $(\mathrm{p}<0.05)$ higher HRSA than the $>1 \mathrm{kDa}$ peptide fractions. The stronger HRSA of the $<1 \mathrm{kDa}$ peptides may have been favored by its low molecular weight, which would have enhanced peptide interactions with the hydroxyl radical molecules [Koopman et al., 2009]. Similar findings showing that the $<1 \mathrm{kDa}$ peptides had better HRSA than the other peptide fractions were previously reported for chickpea peptides [Li et al., 2008].

\section{Metal chelating activity (MCA)}

The MCA principle involves the formation of colored complexes with ferrous iron molecules when a test compound competes with a synthetic chelator [Nam et al., 2008]. The extent of color change, which accompanies the complex compound formation, is used to estimate the chelating activity of the antioxidant test compound. Table 3 shows that FLI and $\mathrm{PH}$ were better metal chelators when compared to $\mathrm{AH}$, $\mathrm{CH}$, and $\mathrm{TH}$, which suggests that enzymatic hydrolysis did not improve the MCA of the hydrolysates. The similar MCA values for FLI and PH may be attributed to the threonine and serine contents, which are higher than the levels present in $\mathrm{AH}, \mathrm{CH}$, and $\mathrm{TH}$. This is because serine and threonine can ionize to produce negative charges that will then enable stronger interactions with the ferrous iron [Mirzaei et al., 2016].
The MCA values for $\mathrm{AH}$ peptide fractions $\left(\mathrm{EC}_{50}: 2.914\right.$ to $3.481 \mathrm{mg} / \mathrm{mL}$ ) indicate stronger metal chelators when compared to the unfractionated hydrolysate $\left(\mathrm{EC}_{50}: 4.903 \mathrm{mg} / \mathrm{mL}\right)$ and GSH. The results suggest that membrane separation reduced the antagonistic peptide interactions present in $\mathrm{AH}$. The 1-3 $\mathrm{kDa}$ peptides had the strongest MCA with a lower $\mathrm{EC}_{50}$ value while the chelating activities of $<1 \mathrm{kDa}$, 3-5 kDa, 5-10 kDa peptide fractions were not significantly $(p>0.05)$ different from each another. A previous report also reported that the 1-3 $\mathrm{kDa}$ peptide fraction of perilla seed protein hydrolysate exhibited greater metal chelating ability than the other fractions [Park \& Yoon, 2019].

\section{Ferric reducing antioxidant power (FRAP)}

The FRAP assay estimates the potential of antioxidant compounds to donate electron/hydrogen ions and interrupt propagation of chain reactions involving free radicals [Dorman et al., 2003]. The FRAP values of the fluted pumpkin protein hydrolysates $(0.166$ to $0.287 \mathrm{mM}$ ) were significantly $(\mathrm{p}<0.05)$ higher compared to the protein isolate (Figure 2A), which suggests that enzymatic hydrolysis improved the reducing property of the protein hydrolysates. This may be due to protein fragmentation and the accompanying increased number of $\mathrm{N}$ - and C-terminals, which contain electrondonating groups $\left(\mathrm{NH}_{2}\right.$ and $\mathrm{COOH}$, respectively) [Jia et al., 2013]. Previous works reported FRAP values of between 0.045 and $0.125 \mathrm{mM}$ for alfalfa leaf protein hydrolysates [Xie et al., 2008] and between 0.01 and $0.35 \mathrm{mM}$ for hawk tea hydrolysates [Jia et al., 2013]. Among the protein hydrolysates, chymotrypsin hydrolysate showed stronger reducing property when compared to the other protein hydrolysates. This is consistent with the smaller average molecular weight of $\mathrm{CH}$ as shown in Figure 1, which suggests that the reduced peptide chain length may have enhanced reduction of $\mathrm{Fe}^{3+}$ when compared to the longer peptides present in $\mathrm{AH}, \mathrm{TH}$, and $\mathrm{PH}$.

The FRAP of the Alcalase peptide fractions ranged between 0.234 and $0.313 \mathrm{mM}$ (Figure 2B). In general, FRAP values were higher in the fractions when compared with values of the unfractionated hydrolysate, which suggests that the ultrafiltration membrane process improved the capacity of the resulting peptides to donate electrons. The increased FRAP potency after membrane separation suggests a positive effect through the reduction of antagonistic peptide interactions within the unfractionated hydrolysate. The $<1 \mathrm{kDa}$ peptide fraction exhibited the highest ferric reducing antioxidant power among the membrane fractions, which is consistent with a previous report on fish hound peptide fractions [Bougatef et al., 2009]. This is an indication that low molecular weight peptides have stronger potentials than bigger peptides for effective reduction of $\mathrm{Fe}^{3+}$.

\section{Lipid peroxidation inhibition}

Lipid oxidation is an important chain reaction process because of the damaging effects on food and biological systems. It is a major cause of quality deterioration, such as the rancidity development and loss in nutritional values of foods [Elias et al., 2008]. In human systems, lipid oxidation and its by-products have been linked to a number of chronic inflammatory and neurogenerative diseases, 

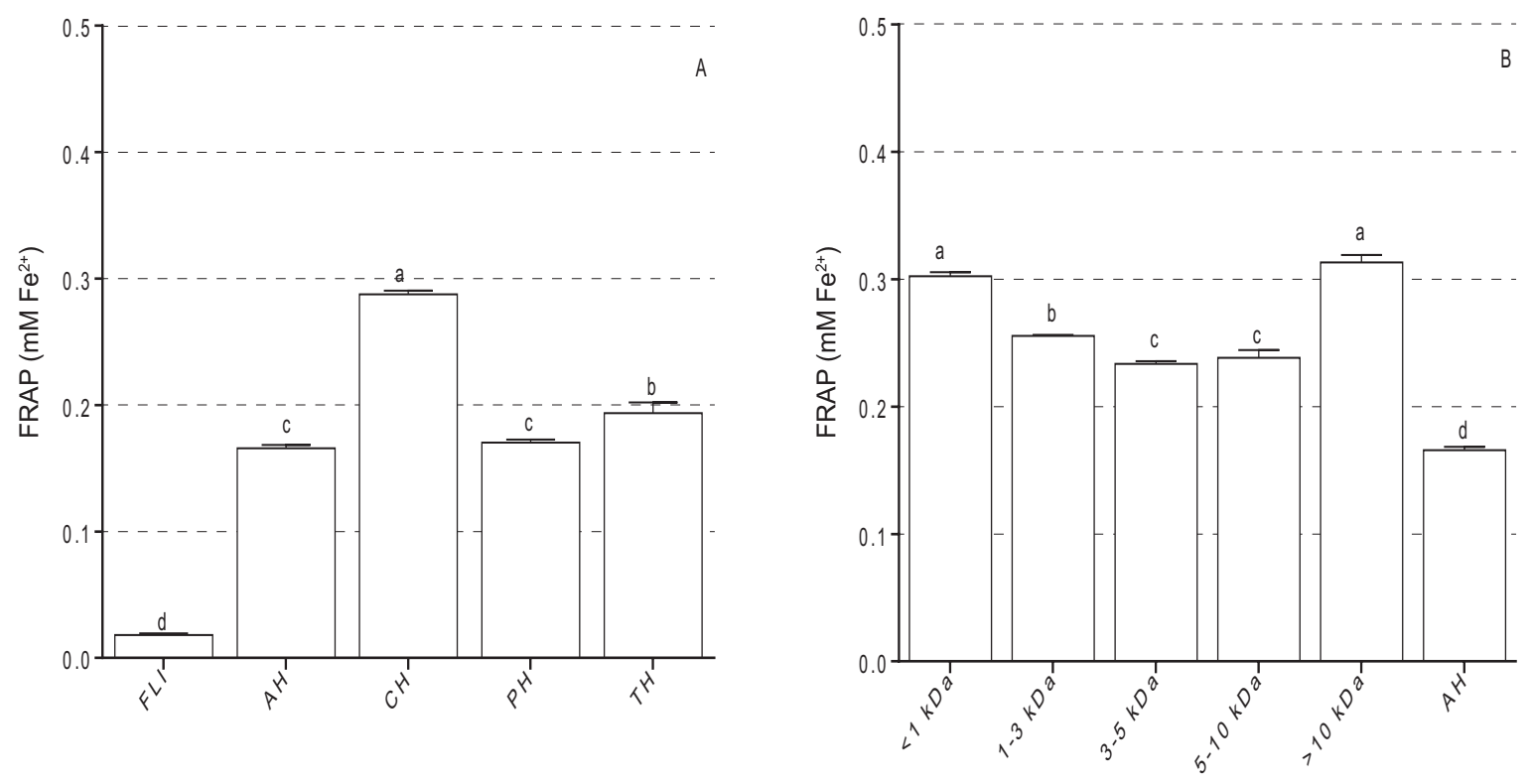

FIGURE 2. Ferric reducing antioxidant power (FRAP) of fluted pumpkin leaf protein isolate (FLI), Alcalase (AH), chymotrypsin (CH), pepsin (PH), trypsin $(\mathrm{TH})$ hydrolysates (A), and AH peptide fractions (B). Different letters above bars indicate significant differences $(\mathrm{p}<0.05)$.

making it of great interest for human health. The inhibition of linoleic acid oxidation is a standardized method developed to evaluate the stability of fats and oils under elevated temperatures [Jia et al., 2013]. Any antioxidant compound that delays or inhibits the oxidation of unsaturated fatty acids in vitro would probably show similar effects in vivo. The inhibition of lipid oxidation by fluted pumpkin leaf isolate and hydrolysates over a period of seven days of incubation is shown in Figure 3. Absorbance of the control (without antioxidant compound) increased on the $1^{\text {st }}$ incubation day and attained its peak absorbance value on the $2^{\text {nd }}$ day (0.881). The values, however, decreased progressively for the rest of the five days. The decrease in the absorbance of the control may be attributed to rapid depletion of linoleic acid coupled with decomposition of the hydroperoxides as the reaction progressed. This is consistent with data from a previous work on pumpkin seed protein hydrolysates [Venuste et al., 2013]. The peak absorbance values of oxidation of linoleic acid with glutathione (0.175) and fluted pumpkin leaf isolate $(0.455)$ occurred on the first day of incubation and decreased for the rest of the incubation days. These values were higher than the peak values of oxidation of lipids with protein hydrolysates, which occurred on the $3^{\text {rd }}$ day for $\mathrm{CH}(0.096)$, and $4^{\text {th }}$ day for $\mathrm{AH}(0.082), \mathrm{PH}(0.083)$, and TH (0.088). This pattern of results suggests that hydrolysis improved the inhibition of the linoleic acid oxidation. The stronger inhibition of linoleic acid oxidation exhibited by protein hydrolysates over the protein isolate may be related to protein fragmentation that would have increased charge density (for electron donation) and reduced peptide size (better interactions with free radicals). Moreover, the increased electron donating ability of the protein hydrolysates, as reflected in the stronger DRSA and FRAP, may have contributed to the better inhibition of lipid peroxidation when compared to the unhydrolyzed protein (FLI).

\section{Enzyme inhibitory properties}

\section{$\alpha$-Amylase inhibitory activities}

$\alpha$-Amylase is an enzyme responsible for hydrolyzing the linear chain of starch molecules, which results in the production of shorter chains (mainly di- and tri-saccharides) that are further broken down by other enzymes into absorbable glucose; therefore, inhibition of this enzyme activity would contribute to the management of diabetics and obesity in humans [Habtamu et al., 2019]. The $\alpha$-amylase inhibitory activity of the hydrolysates ranged between 42.47 and $46.84 \%$, and was significantly $(\mathrm{p}<0.05)$ higher

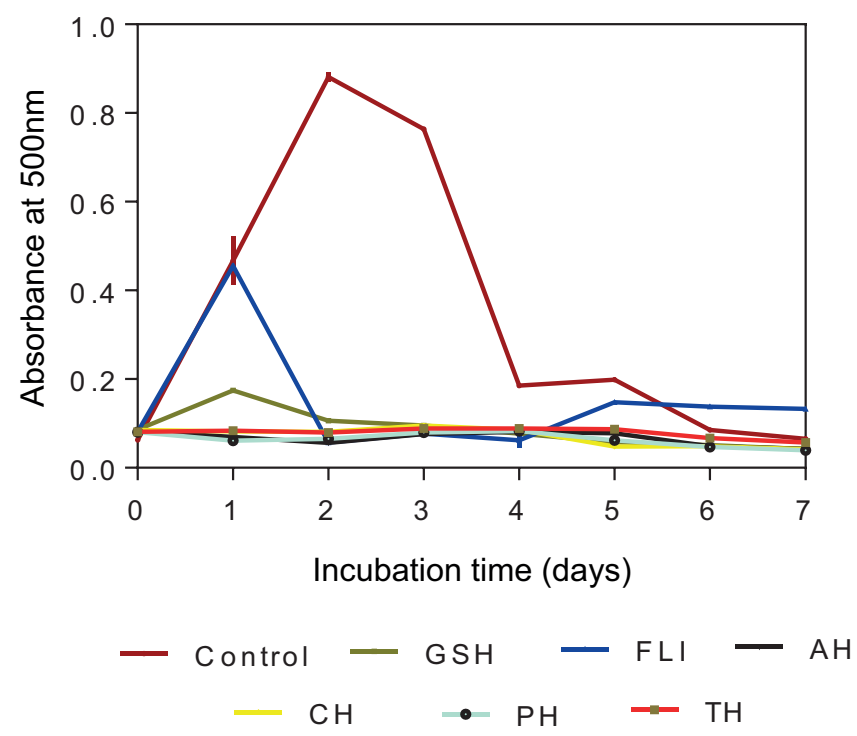

FIGURE 3. Inhibition of linoleic peroxidation by fluted pumpkin leaf protein isolate (FLI) and Alcalase (AH), chymotrypsin $(\mathrm{CH})$, pepsin $(\mathrm{PH})$, and trypsin $(\mathrm{TH})$ hydrolysates. 

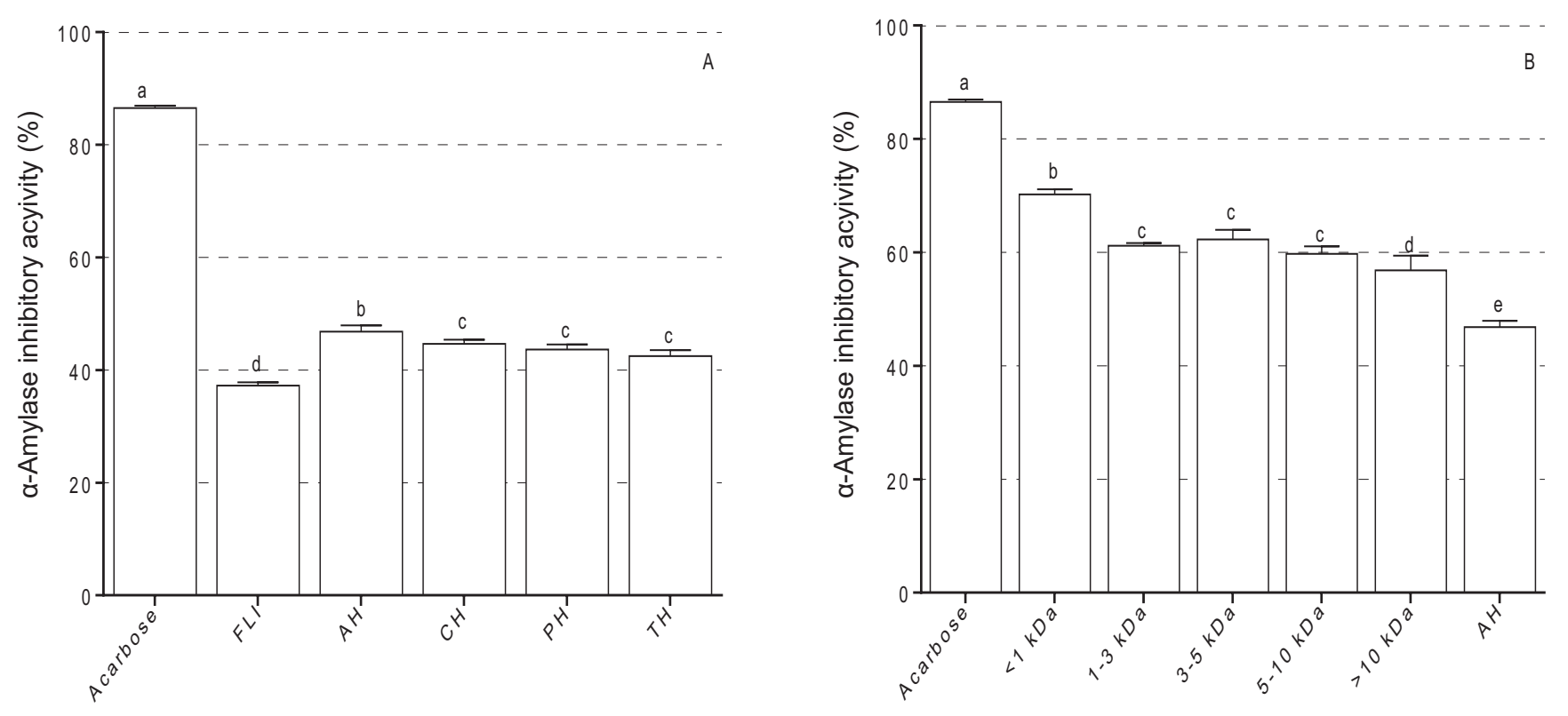

FIGURE 4. $\alpha$-Amylase inhibitory activities of fluted pumpkin leaf protein isolate (FLI) and Alcalase (AH), chymotrypsin (CH), pepsin (PH), trypsin (TH) hydrolysates (A), and AH peptide fractions (B). Different letters above bars indicate significant differences $(\mathrm{p}<0.05)$.

than the $37.24 \%$ determined for FLI (Figure 4A). Therefore, proteolysis led to improved inhibitory properties of the hydrolysates against $\alpha$-amylase. The positive effect of proteolysis on $\alpha$-amylase inhibition may be due to the production of multiple peptide products that can interact with the enzyme protein when compared to the few polypeptide chains present in the FLI. The results show that AH was the most effective $\alpha$-amylase inhibitor and that its inhibitory activity may be related to the higher content of BCAA when compared to $\mathrm{CH}, \mathrm{PH}$, and $\mathrm{TH}$. However, the inhibitory values obtained in this work were lower than the $70-80 \%$ previously reported for cowpea protein hydrolysates [Olusola \& Ekun, 2019] and 60 to 77\% for watermelon seed protein hydrolysates [Arise et al., 2016]. The $\alpha$-amylase inhibitory properties of Alcalase hydrolysate peptide fractions are presented in Figure 4B. The 56.83 to $70.22 \%$ inhibitory levels are higher than the $46.84 \%$ obtained for the unfractionated protein hydrolysate. Improved $\alpha$-amylase inhibition by the peptide fractions suggests reduced peptide antagonism, which enhanced interactions with the enzyme protein. However, the $\alpha$-amylase inhibitory activity of the protein hydrolysates and peptide fractions is lower than the $86.54 \%$ noted for acarbose (a commercial drug). Among the fractions, the $<1 \mathrm{kDa}$ peptides showed greater inhibition, which is consistent with increased ability of small size peptide to interact with the $\alpha$-amylase protein.

\section{$\alpha$-Glucosidase inhibitory activities}

In the human system, $\alpha$-glucosidase breaks down dietary short-chain carbohydrates to produce glucose for intestinal absorption, which leads to an increase in blood glucose levels. Therefore, the inhibition of $\alpha$-glucosidase activity would slow down glucose absorption and attenuate blood glucose levels following meals, which is one of the effective ways to manage diabetes [Arise et al., 2016]. The $\alpha$-glucosidase in- hibitory properties of the hydrolysates (13.87 to $23.76 \%$ ) were higher than the $6.79 \%$ determined for fluted protein isolate (Figure 5A). The results also showed that the inhibition of $\alpha$-glucosidase activity differed among the hydrolysates, which may be related to differences in the proteolytic specificity of the enzymes used during protein digestion. This pattern of results showing the enzyme-dependent activity of protein hydrolysates is consistent with previously published works on watermelon seed hydrolysates [Arise et al., 2016] and soy protein hydrolysates [Wang et al., 2019]. The $<1 \mathrm{kDa}, 1-3 \mathrm{kDa}$, and $>10 \mathrm{kDa}$ peptide fractions had stronger $\alpha$-glucosidase inhibitory activities when compared with the unfractionated $\mathrm{AH}$, while there was no significant difference $(\mathrm{p}>0.05)$ between the 3-5 kDa peptide fraction and the parent $\mathrm{AH}$. This may suggest that some of the peptide fractions had reduced peptide-peptide interactions and better peptide-enzyme interactions when compared to the unfractionated hydrolysate (Figure 5B). Unlike the $\alpha$-amylase inhibition, the $<1 \mathrm{kDa}$ (28.26\%) and $1-3 \mathrm{kDa}(27.38 \%)$ had similar $\alpha$-glucosidase inhibitory activity but were weaker inhibitors than the $>10 \mathrm{kDa}$ peptide fraction. Therefore, peptide molecular weight does not seem to play an important role in the $\alpha$-glucosidase inhibitory activity of the peptide fractions. The results suggest differences in the mode of action of $\alpha$-amylase and $\alpha$-glucosidase in addition to variations in how the enzymes interact with inhibitory peptides.

\section{Angiotensin-converting enzyme (ACE)-inhibitory properties}

$\mathrm{ACE}$ is a multi-functional enzyme that plays vital roles in the regulation of blood pressure, and inhibition of its activity can lead to a reduction in the angiotensin II concentration with concomitant attenuation of hypertension, which can cause many cardiovascular diseases [Zhang et al., 2006]. The ACE-inhibitory $\mathrm{IC}_{50}$ values show significant $(\mathrm{p}<0.05)$ increase in potency after enzymatic hydrolysis of FLI 

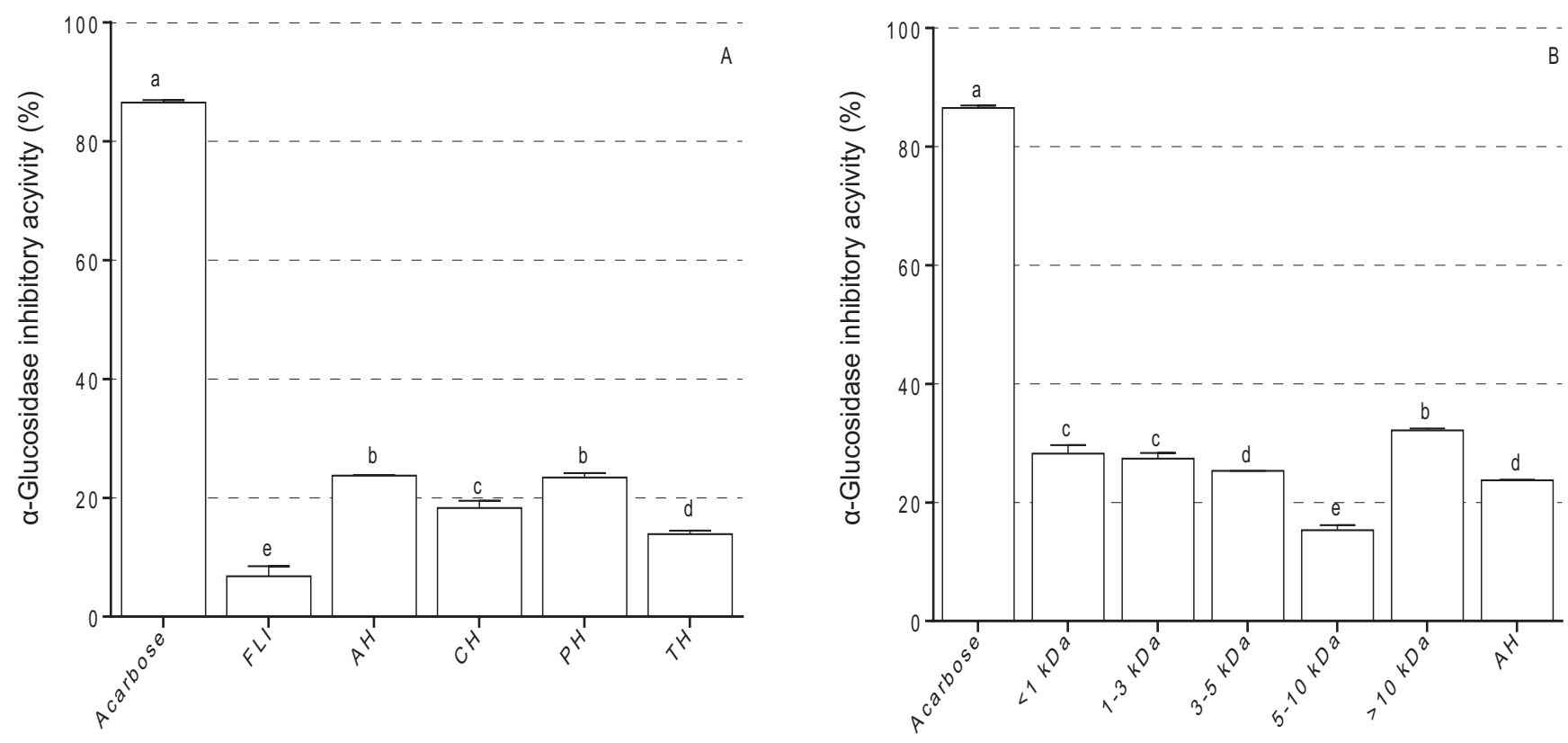

FIGURE 5. $\alpha$-Glucosidase inhibitory activities of fluted pumpkin leaf protein isolate (FLI) and Alcalase (AH), chymotrypsin (CH), pepsin (PH), trypsin $(\mathrm{TH})$ hydrolysates $(\mathrm{A})$, and AH peptide fractions (B). Different letters above bars indicate significant differences $(\mathrm{p}<0.05)$.

(Table 3). This pattern may be attributed to an increased number of peptide molecules in the hydrolysates when compared to the few polypeptide molecules in FLI. Moreover, the smaller peptides may have better interactions with the enzyme active site than the big FLI protein molecules. There was no significant $(p<0.05)$ difference in the ACEinhibitory properties of $\mathrm{CH}$ and $\mathrm{AH}$, but these two hydrolysates had lower $\mathrm{IC}_{50}$ values $(0.666$ and $0.675 \mathrm{mg} / \mathrm{mL}$, respectively), which suggest their greater inhibitory potency when compared to PH (1.432 mg/mL) and TH $(0.889 \mathrm{mg} /$ $\mathrm{mL})$. $\mathrm{CH}$ and $\mathrm{AH}$ also had higher contents of aromatic amino acids (AAA), BCAA, HAA, and sulfur-containing amino acids (SCAA) as shown in Table 1, which may have contributed to the superior ACE--inhibitory properties when compared to $\mathrm{PH}$ and $\mathrm{TH}$. The results are consistent with previous works on chickpea [Medina--Godoy et al., 2012] and lupin [Boschin et al., 2014] protein hydrolysates with strong ACE-inhibitory activities attributed to the high level of hydrophobic amino acids.

The ACE-inhibitory $\mathrm{IC}_{50}$ values of Alcalase peptide fractions ranged from 0.217 to $0.446 \mathrm{mg} / \mathrm{mL}$, and were significantly lower (more potency) when compared to the unfractionated hydrolysate (Table 3 ). The 1-3 $\mathrm{kDa}$ peptide fraction showed the strongest $(\mathrm{p}<0.05)$ ACE inhibition $\left(\mathrm{IC}_{50}=0.217 \mathrm{mg} / \mathrm{mL}\right)$, whereas there were no significant differences between $<1 \mathrm{kDa}$ $(0.340 \mathrm{mg} / \mathrm{mL}), 3-5 \mathrm{kDa}(0.372 \mathrm{mg} / \mathrm{mL})$, and $5-10 \mathrm{kDa}$ fractions $(0.356 \mathrm{mg} / \mathrm{mL})$. In contrast, the $>10 \mathrm{kDa}$ peptide fraction was the weakest $(0.446 \mathrm{mg} / \mathrm{mL})$ ACE inhibitor. The ACE-inhibitory $\mathrm{IC}_{50}$ values obtained in this study for peptide fractions were lower when compared to the $3.00-3.64 \mathrm{mg} / \mathrm{mL}$ reported for Leucopaxillus tricolor [Geng et al., 2016], 0.50-2.00 mg/mL for Fucus spirallis [Paiva et al., 2017], and 0.615-1.975 mg/mL for sea cucumber Acaudina molpadioidea [Zhao et al., 2009] protein hydrolysates.

\section{CONCLUSIONS}

In this study, four proteases were used to hydrolyze fluted pumpkin leaf protein isolate into hydrolysates with a distinct degree of hydrolysis, peptide molecular weight distribution, and amino acid composition, which contributed to variations observed in antioxidant and enzyme ( $\alpha$-amylase, $\alpha$-glucosidase, and ACE) inhibitory properties. The results of the peptide sequencing showed that the hydrolysate contained dipeptides, tripeptide, and tetrapeptides, and the presence of these short peptides may contribute to the bioactivities of the hydrolysates. The AH was fractionated into peptides of varying molecular weights with the $<1 \mathrm{kDa}$ showing better overall antioxidant and enzyme-inhibitory properties. The results support previous works in scientific literature that have shown stronger bioactive properties of small size peptides when compared to the bigger peptides. Membrane ultrafiltration separation of AH led to an increase in the in vitro bioactive properties, which supports the use of this method in enriching peptide fractions with active molecules. Therefore, the resulting peptides, especially the low molecular weight fractions, may find application as ingredients in the food and nutrition industries to formulate functional foods and nutraceuticals for the management of oxidative stress, hyperglycemia, and hypertension. However, in vivo studies that use animal models are required to validate bioactive properties of the peptides.

\section{RESEARCH FUNDING}

This research was supported by the International Development Research Centre and Global Affairs Canada through the Canadian International Food Security Research 
Fund, Project 107983 on synergizing indigenous vegetables and fertilizer micro-dosing innovations among West African farmers.

\section{CONFLICT OF INTERESTS}

There is no conflict of interest in the publication of the article. All the authors agreed to the submission of this work.

\section{ORCID IDs}

A.A. Famuwagun https://orcid.org/0000-0003-1474-1785

K.A. Taiwo https://orcid.org/0000-0003-4353-8591

R.E. Aluko https://orcid.org/0000-0002-9025-2513

\section{REFERENCES}

1. Ajibola, C.F., Fashakin, J.B., Fagbemi, T.N., Aluko, R.E. (2011). Effect of peptide size on antioxidant properties of african yam bean seed (Sphenostylis stenocarpa) protein hydrolysate fractions. International Journal of Molecular Sciences, 12, 6685-6702. https://doi.org/10.3390/ijms12106685

2. Alashi, A.M., Blanchard, C.L., Mailer, R.J., Agboola, S.O., Mawson, A.J., Rong, H., Malomo, S.A., Girgih, A.T., Aluko, R.E. (2014). Blood pressure lowering effects of Australian canola protein hydrolysates in spontaneously hypertensive rats. Food Research International, 55, 281-287.

https://doi.org/10.1016/j.foodres.2013.11.015

3. Aletor, O., Oshodi, A.A., Ipinmoroti, K. (2002). Chemical composition of common leafy vegetables and functional properties of their leaf protein concentrates. Food Chemistry, 78(1), 63-68. https://doi.org/10.1016/S0308-8146(01)00376-4

4. Aluko, R.E. (2015). Antihypertensive peptides from food proteins. Annual Review of Food Science and Technology, 6(1), 235-262. https://doi.org/10.1146/annurev-food-022814-015520

5. Arise, R.O., Yekeen, A., Ekun, O. (2016). In-vitro antioxidant and $\alpha$-amylase inhibitory properties of watermelon seed protein hydrolysates. Environmental and Experimental Biology, 14(4), 163-172.

https://doi.org/10.22364/eeb.14.23

6. Awosika, T.O., Aluko, R.E. (2019). Inhibition of the in vitro activities of $\alpha$-amylase, $\alpha$-glucosidase and pancreatic lipase by yellow field pea (Pisum sativum L.) protein hydrolysates. International Journal of Food Science and Technology, 54(6), 2021-2034. https://doi.org/10.1111/ijfs.14087

7. Benzie, I.F.F., Strain, J.J. (1996). Ferric reducing ability of plasma (FRAP) as a measure of antioxidant power: The FRAP assay. Analytical Biochemistry, 239(1), 70-76.

https://doi.org/10.1006/abio.1996.0292

8. Bleakley, S., Hayes, M., O'Shea, N., Gallagher, E., Lafarga, T. (2017). Predicted release and analysis of novel ACE-I, renin, and DPP-IV inhibitory peptides from common oat (Avena sativa) protein hydrolysates using in silico analysis. Foods, 6(12), art. no. 108 .

\section{https://doi.org/10.3390/foods6120108}

9. Boschin, G., Scigliuolo, G.M., Resta, D., Arnoldi, A. (2014). ACE-inhibitory activity of enzymatic protein hydrolysates from lupin and other legumes. Food Chemistry, 145, 34-40.

https://doi.org/10.1016/j.foodchem.2013.07.076
10. Bougatef, A., Hajji, M., Balti, R., Lassoued, I., Triki-Ellouz, Y., Nasri, M. (2009). Antioxidant and free radical-scavenging activities of smooth hound (Mustelus mustelus) muscle protein hydrolysates obtained by gastrointestinal proteases. Food Chemistry, 114(4), 1198-1205.

https://doi.org/10.1016/j.foodchem.2008.10.075

11. Cao, W., Zhang, W.C., Hong, P., Ji, H., Hao, J. (2010). Purification and identification of an ACE inhibitory peptide from the peptic hydrolysate of Acetes chinensis and its antihypertensive effects in spontaneously hypertensive rats. International Journal of Food Science and Technology, 45 (5), 959-965.

http://dx.doi.org/10.1111/j.1365-2621.2010.02219.x

12. Chalamaiah, M., Yu, W., Wu, J. (2018). Immunomodulatory and anticancer protein hydrolysates(peptides) from food proteins: a review. Food Chemistry, 245, 205-222. https://doi. org/10.1016/j.foodc hem.2017.10.087

13. Charoenphun, N., Cheirsilp, B., Sirinupong, N. (2013). Calcium binding peptides derived from tilapia (Oreochromis niloticus) protein hydrolysates. European Food Research Technology, 236, 57-63. https://doi.org/10.1007/s00217-012-1860-2

14. Chen, C., Chi, Y.J., Zhao, M.Y., Lv, L. (2012). Purification and identification of antioxidant peptides from egg white protein hydrolysate. Amino Acids, 43, 457-466.

https://doi.org/10.1007/s00726-011-1102-0

15. Dhanda, S., Singh, H., Singh, J., Singh, T.P. (2008) Functional characterization and specific effects of various peptides on enzymatic activity of a DPP-III homologue from goat brain. Journal of Enzyme Inhibition and Medicinal Chemistry, 23(2), 174-181.

https://doi.org/10.1080/14756360701450996

16. Dorman, H.J.D., Peltoketo, A., Hiltunen, R., Tikkanen, M.J. (2003). Characterization of the antioxidant properties of deodorised aqueous extracts from selected Lamiaceae herbs. Food Chemistry, 83(2), 255-262.

https://doi.org/10.1016/S0308-8146(03)00088-8

17. Elias, R.J., Kellerby, S.S., Decker, E.A. (2008). Antioxidant activity of proteins and peptides. Critical Reviews in Food Science and Nutrition, 48(5), 430-441.

https://doi.org/10.1080/10408390701425615

18. Famuwagun, A.A., Alashi, A.M., Gbadamosi, S.O., Taiwo, K.A., Oyedele, D.J., Adebooye, O.C., Aluko, R.E. (2020). Comparative study of the structural and functional properties of protein isolates prepared from edible vegetable leaves. International Journal of Food Properties, 23(1), 955-970.

https://doi.org/10.1080/10942912.2020.1772285

19. Filho, J.G., Rodrigues, J.M., Valadares, A.C.F., de Almeida, A.B., Valencia-Mejia, E., Fernandes, K.F., Lemes, A.C., Alves, C.C.F., Sousa, H.A.F., da Silva, E.R., Egea, M.B., Dyszy, F.H. (2020). Bioactive properties of protein hydrolysate of cottonseed byproduct: Antioxidant, antimicrobial, and angiotensin-converting enzyme (ACE) inhibitory. Waste and Biomass Valorization, 2020. https://doi.org/10.1007/s12649-020-01066-6

20. Gbadamosi, S.O., Famuwagun, A.A. (2016). Studies on the proximate, functional and antioxidant properties of fermented and unfermented Kariya (Hildergardia barterii) seed protein hydrolysates obtained by enzymatic hydrolysis. British Journal of Biotechnology, 14, 1-14. https://doi.org/10.9734/BBJ/2016/26685 
21. Geng, X., Tian, G., Zhang, W., Zhao, Y., Zhao, L., Wang, H., $\mathrm{Ng}$, T.B. (2016). A tricholoma matsutake peptide with angiotensin converting enzyme inhibitory and antioxidative activities and antihypertensive effects in spontaneously hypertensive rats. Scientific Reports, 6, art. no. 24130.

https://doi.org/10.1038/srep24130

22. Girgih, A., Udenigwe, C., Li, H., Adebiyi, A., Aluko, R. (2011). Kinetics of enzyme inhibition and antihypertensive effects of hemp seed (Cannabis sativa L.) protein hydrolysates. Journal of the American Oil Chemists' Society, 88(11), 1767-1774. https://doi.org/10.1007/s11746-011-1841-9

23. Gong, K., Deng, L., Shi, A., Liu, H., Liu, L., Hu, H., Adhikari, B. Wang, Q. (2017). High-pressure microfluidisation pretreatment disaggregates peanut protein isolates to prepare antihypertensive peptide fractions. International Journal of Food Science and Technology, 52(8), 1760-1769.

https://doi.org/10.1111/ijfs.13449

24. Habtamu, A.M., Abdalbasit, A., Gasmalla, R.Y., Wei, Z. (2019). Evaluation of the in vitro $\alpha$-amylase enzyme inhibition potential of commercial dried Laver (Porphyra Species) Seaweed protein hydrolysate. Turkish Journal of Fisheries and Aquatic Sciences, 18(4), 547-556.

https://doi.org/10.4194/1303-2712-v18_4_06

25. He, R., Girgih, A.T., Malomo, S.A., Ju, X., Aluko, R.E. (2013). Antioxidant activities of enzymatic rapeseed protein hydrolysates and the membrane ultrafiltration fractions. Journal of Functional Foods, 5, 219-227.

https://doi.org/10.1016/j.jff.2012.10.008

26. Horton, H.R., Moran, L.A., Ochs, R.S., Rawn, J.D., Scrimgeour, K.G. (2002c). Properties of Enzymes. In Principles of Biochemistry. 3rd Edition. Prentice Education, NJ, pp. 242-244.

27. Jamdar, S.N., Rajalakshmi, V., Sharma, A. (2012). Antioxidant and ACE inhibitory properties of poultry viscera protein hydrolysate and its peptide fractions. Journal of Food Biochemistry, 36(4), 494-501.

https://doi.org/10.1111/j.1745-4514.2011.00562.x

28. Jia, X., Ding, C., Dong, L., Yuan, S., Zhang, Z., Chen, Y., Yuan, M. (2013). Comparison of the chemical and functional properties of protein hydrolysates from different mature degree hawk teas. Journal of Food and Nutrition Research, 1 (6), 138-144. https://doi.org/10.12691/jfnr-1-6-5

29. Kim, S.R., Byun, H.G. (2012). The novel angiotensin I converting enzyme inhibitory peptides from rainbow trout muscle hydrolysate. Fisheries and Aquatic Sciences, 15(3), 183-190. https://doi.org/10.5657/FAS.2012.0183

30. Kim, Y.M., Wang, M.H., Rhee, H.I. (2004). A novel alpha glucosidase inhibitor from pine bark. Carbohydrate Research, 339, 715-727. https:/doi/org/10.1016/j.carres.2003.11.005

31. Koopman, R., Crombach, N., Gijsen, A.P., Walrand, S., Fauquant, J., Kies A.K., van Loon, L.J.C. (2009). Ingestion of a protein hydrolysate is accompanied by an accelerated in vivo digestion and absorption rate when compared with its intact protein. American Journal of Clinical Nutrition, 90(1), 106-115. https://doi.org/10.3945/ajcn.2009.27474

32. Kwon, Y., Apostolidis, E., Shetty, K. (2008). Inhibitory potential of wine and tea against alpha amylase and alpha glucosidase for management of hypertensive linked to type 2 diabetes. Journal of Food Biochemistry, 32(1), 15-31.

https://doi.org/10.1111/j.1745-4514.2007.00165.x

33. Lacroix, I.M.E., Li-Chan, E.C.Y. (2012). Evaluation of the potential of dietary proteins as precursors of dipeptidyl peptidase (DPP)-IV inhibitors by an in-silico approach. Journal of Functional Foods, 4(2), 403-422.

https://doi.org/10.1016/j.jff.2012.01.008

34. Li, Y., Jiang, B., Zhang, T., Mu, W., Liu, J. (2008). Antioxidant and free radical scavenging activities of chickpea protein hydrolysate (CPH). Food Chemistry, 106(2), 444-450.

https://doi.org/10.1016/j.foodchem.2007.04.067

35. Malomo S.A., He, R., Aluko, R.E. (2014). Structural and functional properties of hemp seed protein products. Journal of Food Science, 79, C1512-C1521. https://doi.org/10.1111/1750-3841.12537

36. Malomo, S.A., Aluko, R.E. (2019). Kinetics of acetylcholinesterase inhibition by hemp seed protein-derived peptides. Journal Food Biochemistry, 43(7), art. no. e12897.

https://doi.org/10.1111/jfbc.12897

37. McCarthy, A.L., O'Callaghan, Y.C., O'Brien, N.M. (2013). Protein hydrolysates from agricultural crops-bioactivity and potential for functional food development. Agriculture, 3, 112-130.

https://doi.org/10.3390/agriculture3010112

38. Medina-Godoy, S., Ambriz-Pérez, D.L., Fuentes-Gutiérrez, C., Germán-Báez, L.J., Gutiérrez-Dorado, R., Reyes-Moreno, C., Valdez-Ortiz, A. (2012). Angiotensin-converting enzyme inhibitory and antioxidative activities and functional characterization of protein hydrolysates of hard-to-cook chickpeas. Journal of the Science of Food and Agriculture, 92 (9), 1974-1981. https://doi.org/10.1002/jsfa.5570

39. Mirzaei, M., Aminlari, M., Hosseini, E. (2016). Antioxidant, ACE-Inhibitory and antibacterial activities of Kluyveromyces marxianus protein hydrolysates and their peptide fractions. Functional Foods in Health and Disease, 6(7), 425-439.

https://doi.org/10.31989/ffhd.v6i7.250

40. Mirzaei, M.M., Mirdamadi, S., Ehsani, M.R., Aminlari, M., Hosseini, E. (2015). Purification and identification of antioxidant and ACE-inhibitory peptide from Saccharomyces cerevisiae protein hydrolysate. Journal of Functional Foods, 19, 259-268. https://doi.org/10.1016/j.jf.2015.09.031

41. Muhamyankaka, V., Shoemaker, C.F., Nalwoga, M., Zhang, X.M. (2013). Physicochemical properties of hydrolysates from enzymatic hydrolysis of pumpkin (Cucurbita moschata) protein meal. International Food Research Journal, 20(5), 2227-2240.

42. Nam, K.A., You, S.G., Kim, S.M. (2008). Molecular and physical characteristics of squid (Todarodes pacificus) skin collagens and biological properties of their enzymatic hydrolysates. Journal of Food Science, 73(4), C243-C255.

https://doi.org/10.1111/j.1750-3841.2008.00722.x

43. Nnamezie, A.A., Famuwagun, A.A., Gbadamosi, S.O. (2019). Changes in some nutritional and sensory properties of treated and stored fluted pumpkin leaf. Annals. Food Science and Technology, 20(1), 65-81.

44. Odiaka, N.I. (2001). Survey on the production and supply of Telfairia occidentalis in Makurdi, Benue State Nigeria. African Journal of Food Science, 2, 12-18. 
45. Olagunju, A.I., Omoba, O.S., Enujiugha, V.N., Alashi. A.M., Aluko, R.E. (2018). Pigeon pea enzymatic protein hydrolysates and ultrafiltration peptide fractions as potential sources of antioxidant peptides: An in vitro study. LWT - Food Science and Technology, 97, 269-278.

https://doi.org/10.1016/j.Iwt.2018.07.003

46. Olusola, A.O., Ekun, O.E. (2018). Alpha-Amylase inhibitory properties and in vitro anti-oxidant potentials of cowpea seed protein hydrolysates. AASCIT Communications, 6(1), 1-12.

47. Ortiz-Martinez, M., Winkler, R., García-Lara, S. (2014). Preventive and therapeutic potential of peptides from cereals against cancer. Journal of Proteomics, 111, 165-183.

https://doi.org/10.1016/j.jprot.2014.03.044

48. Paiva, L., Lima, E., Isabel, N., Baptista, J. (2017). Angiotensin I-Converting Enzyme (ACE) inhibitory activity, antioxidant properties, phenolic content and amino acid profiles of Fucus spiralis L. protein hydrolysate fractions. Marine Drugs, 15(10), 3-11. https://doi.org/10.3390/md15100311

49. Park, B.Y., Yoon, K.Y. (2019). Biological activity of enzymatic hydrolysates and the membrane ultrafiltration fractions from perilla seed meal protein. Czech Journal of Food Sciences, 37(3), 180-185. https://doi.org/10.17221/145/2018-CJFS

50. Pihlanto, A., Mäkinen, S. (2017). The function of renin and the role of food-derived peptides as direct renin inhibitors. In A. N. Tolekova (Ed.), Renin-Angiotensin System-Past, Present And Future. InTech Open, London, UK, pp. 241-258. https://doi.org/10.5772/intechopen.69513

51. Pinciroli, M., Aphalo, P., Nardo, A.E., Añón, M.C., Quiroga, A.V. (2019). Broken rice as a potential functional ingredient with inhibitory activity of renin and angiotensin-converting enzyme (ACE). Plant Foods for Human Nutrition, 74(3), 405-413. https://doi.org/10.1007/s11130-019-00754-6

52. Rajapakse, N., Mendis, E., Byun, H.G., Kim, S.K. (2005). Purification and in vitro antioxidative effects of giant squid muscle peptides on free radical-mediated oxidative systems. Journal of Nutritional Biochemistry, 16(9), 562-569. https://doi.org/10.1016/j.jnutbio.2005.02.005

53. Ramada, M.H.S., Brand, G.D., Abrão, F.Y., Oliveira, M., Filho, J.L.C., Galbieri, R., Gramacho, K.P., Prates, M.V., Bloch, C. (2017). Encrypted antimicrobial peptides from plant proteins. Scientific Reports, 7, art. no. 13263. https://doi.org/10.1038/s41598-017-13685-6

54. Saidi, S., Deratani, A., Belleville M.P., Amar, R.B. (2014). Antioxidant properties of peptide fractions from tuna dark muscle protein by-product hydrolysate produced by membrane fractionation process. Food Research International, 65, 329-336.

55. Sentandreu, M.A., Toldrá, F. (2006). A rapid, simple and sensitive fluorescence method for the assay of angiotensin-I converting enzyme. Food Chemistry, 97(3), 546-554. https://doi.org/10.1016/j.foodchem.2005.06.006

56. Tavano, O.L. (2013). Protein hydrolysis using proteases: an important tool for food biotechnology. Journal of Molecular Catalysis and Biological Enzymology, 90, 1-11. https://doi.org/10.1016/j.molcatb.2013.01.011

57. Thamnarathip, P., Jangchud, K., Nitisinprasert, S., Vardhanabhuti, B. (2016). Identification of peptide molecular weight from rice bran protein hydrolysate with high antioxidant activity. Journal of Cereal Science, 69, 329-335. https://doi.org/10.1016/j.jcs.2016.04.011
58. The UniProt Consortium (2019). UniProt: a worldwide hub of protein knowledge. Nucleic Acids Research, 47(D1), D506-D515. https://doi.org/10.1093/nar/gky1049

59. Udenigwe, C.C., Aluko, R.E. (2012). Food protein-derived bioactive peptides; Production, processing, and potential health benefits. Journal of Food Science, 77(1), R11-R24.

https://doi.org/10.1111/j.1750-3841.2011.02455.x

60. Udenigwe, C.C., Lin, Y.S., Hou, W.C., Aluko, R.E. (2009). Kinetics of the inhibition of renin and angiotensin, I-converting enzyme by flaxseed protein hydrolysate fractions. Journal of Functional Foods, 1, 199-207.

https://doi.org/10.1016/j.jff.2009.01.009

61. Udousoro, I., Ekanem, P. (2013). Assessment of proximate compositions of twelve edible vegetables in Nigeria. International Journal of Modern Chemistry, 4(2), 79-89.

62. Venuste, M., Zhang, X., Shoemaker, C.F., Karangwa, E., Abbas, S., Kamdem, P.E. (2013). Influence of enzymatic hydrolysis and enzyme type on the nutritional and antioxidant properties of pumpkin meal hydrolysates. Food and Function, 4, 811-820. https://doi.org/10.1039/c3fo30347k

63. Wang, R., Zhao, H., Pan, X., Orfila, C., Lu, W., Ma, Y. (2019). Preparation of bioactive peptides with antidiabetic, antihypertensive, and antioxidant activities and identification of $\alpha$-glucosidase inhibitory peptides from soy protein. Food Science and Nutrition, 7(5), 1848-1856.

https://doi.org/10.1002/fsn3.1038

64. Wasswa, J., Tang, J., Gu, X.-H., Yuan, X.-Q. (2007). Influence of the extent of enzymatic hydrolysis on the functional properties of protein hydrolysate from grass carp (Ctenopharyngodon idella) skin. Food Chemistry, 104, 1698-1704.

https://doi.org/10.1016/j.foodchem.2007.03.044

65. Wei, Y.-H., Lu, C.-Y., Wei, C.-Y., Ma, Y.-S., Lee, H.-C. (2001). Oxidative stress in human aging and mitochondrial disease-consequences of defective mitochondrial respiration and impaired antioxidant enzyme system. Chinese Journal of Physiology, 44(1), 1-11.

66. Xie, Z., Huang, J., Xu, X., Jin, Z. (2008). Antioxidant activity of peptides isolated from alfalfa leaf protein hydrolysate. Food Chemistry, 111, 370-376. https://doi.org/10.1016/j.foodchem.2008.03.078

67. Yoshikawa, T., Naito, Y. (2002). What is oxidative stress? Japanese Medical Association Journal, 45(7), 271-276.

68. Zhang, Y., Lee, E.T., Devereux, R.B., Yeh, J., Best, L.G., Fabsitz, R.R., Howard, B.V. (2006). Prehypertension, diabetes, and cardiovascular disease risk in a population-based sample: The strong heart study. Hypertension, 47, 410-414. https://doi.org/10.1161/01.HYP.0000205119.19804.08

69. Zhao, Y., Li, B., Dong, S., Liu, Z., Zhao, X., Wang, J., Zeng, M.A. (2009). Novel ACE inhibitory peptide isolated from Acaudina molpadioidea hydrolysate. Peptides, 30, 1028-1033. https://doi.org/10.1016/j. peptides.2009.03.002

70. Zhu, K.X., Zhou, H.M., Qian, H.F. (2006). Antioxidant and free radical-scavenging activities of wheat germ protein hydrolysates (WGPH) prepared with Alcalase. Process Biochemistry, 41, 1296-1302.

https://doi.org/10.1016/j.procbio.2005.12.029

Submitted: 25 August 2020. Revised: 2 October, 3 November, and 10 November 2020. Accepted: 12 November 2020. Published on-line: 9 December 2020. 